\title{
New Frontiers in the Treatment of Multiple Myeloma
}

\author{
Janice Jin Hwang ${ }^{1}$, Irene M. Ghobrial ${ }^{1,2}$, and Kenneth C. Anderson ${ }^{1,2, *}$ \\ ${ }^{1}$ Harvard Medical School, Boston, MA; ${ }^{2}$ Jerome Lipper Multiple Myeloma Center, \\ Department of Medical Oncology, Dana Farber Cancer Institute, Boston, MA \\ E-mail: Kenneth anderson@dfci.harvard.edu
}

Received June 17, 2006; Revised August 29, 2006; Accepted October 3, 2006; Published December 6, 2006

\begin{abstract}
Recent leaps in elucidating the biology of myeloma, particularly the intracellular pathways and the complex interaction with the bone marrow microenvironment, have resulted in an unprecedented surge of novel, targeted therapies and therapeutic regimens. There are currently over $30 \mathrm{new}$ agents being tested in the treatment of multiple myeloma (MM). Many of these are novel, targeted agents that have demonstrated significant efficacy and prolonged survival. In this review, we summarize the current understanding of the mechanisms of action of novel therapies being tested in the preclinical and clinical settings in MM. These include agents that act directly on the intracellular signaling pathways, cell maintenance processes, and cell surface receptors. Finally, we present the clinical responses to some of these agents when used alone or in combination in clinical trials of patients with MM. Indeed, MM has become a model disease for the development of novel, therapeutic agents.
\end{abstract}

KEYWORDS: multiple myeloma, signaling pathways, novel therapy, interleukin-6 (IL-6), proteasome inhibitor, thalidomide

\section{INTRODUCTION}

The first case descriptions of multiple myeloma (MM), a plasma cell malignancy characterized by lytic bone lesions, anemia, hypercalcemia, and renal failure, occurred as early as 1844 in patients described as having "mollities ossium" (soft bones); at the time, leeches and therapeutic bleeding were common treatment options[1,2]. It was not until over a century later, in 1958, that melphalan was first reported as a successful treatment for myeloma[3]. Shortly afterwards, melphalan combined with prednisone (MP) achieved better results than melphalan alone, and MP remained the conventional regimen until the recent advances of therapy in MM[4]. Recent leaps in elucidating the biology of myeloma, particularly the intracellular pathways and the complex interaction with the bone marrow microenvironment, have resulted in an unprecedented surge of novel, targeted therapies and therapeutic regimens. There are currently over 30 new agents being tested in the treatment of MM. Many of these are novel, targeted agents that have demonstrated significant efficacy and prolonged survival. Indeed, there has been a paradigm shift in the treatment of MM in the last 5 years.

Here, we provide a brief summary of the pathophysiology of MM, emphasizing the important role of the bone marrow microenvironment, and describing the mechanisms and pathways associated with novel 
therapies. We will discuss the preclinical evidence supporting novel therapies that target intracellular signaling pathways (Table 1), cell maintenance processes (Table 2), and cell surface receptors (Table 3). Finally, we will discuss therapies currently showing great promise in clinical trials both as single agents, and more importantly, in combination.

TABLE 1

Novel Agents Targeting Intracellular Signaling Pathways

\begin{tabular}{|c|c|c|c|}
\hline Pathways & Novel Agent & Description & Status \\
\hline \multirow[t]{5}{*}{ PI3K/Akt } & Perifosine & Alkylphosphocholine & Phase II \\
\hline & Rapamycin & mTOR inhibitor & \\
\hline & $\mathrm{CCl}-779$ & & Phase II \\
\hline & RAD-001 & & Phase II \\
\hline & Enzastaurin & $P K C \beta$ inhibitor & Phase II \\
\hline \multirow[t]{5}{*}{ MEK/ERK } & Tipifarnib & Farnesyltransferase inhibitor & Phase II \\
\hline & L744832 & & \\
\hline & Manumycin & & \\
\hline & BMS-214662 & & \\
\hline & Lonafarnib & & \\
\hline p38 MAPK & SCIO-469 & p38 MAPK inhibitor & Preclinical \\
\hline MAPK/JNK & Aplidin/plitidepsin & & Phase II \\
\hline \multirow[t]{2}{*}{ NF-кB } & PS-1145 & IKK inhibitor & Preclinical \\
\hline & Bortezomib & Proteasome inhibitor & $\begin{array}{l}\text { Phase } \\
\text { III/FDA } \\
\text { approved }\end{array}$ \\
\hline JAK/STAT & Atiprimod & Azaspirane & Preclinical \\
\hline \multirow[t]{9}{*}{ Apoptosis } & Arsenic trioxide & & Phase II \\
\hline & LPAAT inhibitor & & Preclinical \\
\hline & 2-Methoxyestradiol & & Preclinical \\
\hline & ABT-737 & Bcl-2 inhibitor & Preclinical \\
\hline & CDDO-Im & Triterpenoid & Preclinical \\
\hline & VX-944 & Inosine monophosphate dehydrogenase inhibitor & Preclinical \\
\hline & PK1195 & Smac mimetic & Preclinical \\
\hline & FTY720 & Sphingosine monophosphate inhibitor & Preclinical \\
\hline & Etodolac & & Preclinical \\
\hline \multirow[t]{3}{*}{ Multiple pathways } & Thalidomide & & Phase III \\
\hline & Lenalidomide/Revlimid & & Phase III \\
\hline & CC-4047/Actimid & & Phase III \\
\hline
\end{tabular}

\section{PATHOGENESIS OF MULTIPLE MYELOMA}

Although MM is usually defined as a malignancy of the plasma cell, there is strong evidence to suggest that the initial mutation may have occurred in a less-differentiated cell[5]. Malignant plasma cells are usually immature plasmablasts that exhibit numerous chromosomal abnormalities. While a full discussion of the initial pathogenesis of disease is beyond the scope of this review, it is important to note that early 
TABLE 2

Novel Agents Targeting Cell Maintenance Processes

\begin{tabular}{llll}
\hline Cell Maintenance Process & Novel Agent & \multicolumn{1}{c}{ Description } & \multicolumn{1}{c}{ Status } \\
\hline Protein degradation & Bortezomib/Velcade & Proteasome inhibitor & FDA-approved phase III \\
& NPI-0052 & & Preclinical \\
& Tubacin & Aggresome inhibitor & Preclinical \\
Transcription & SAHA & HDAC inhibitor & Phase I \\
& NVP-LAQ824 & & Preclinical \\
& NVP-LBH589 & & Preclinical \\
Protein chaperoning & 17AAG & Hsp90 inhibitor & Phase I/II \\
Mitosis & GRN163 & Telomerase inhibitor & Preclinical \\
\hline
\end{tabular}

TABLE 3

Novel Agents Targeting Cell Surface Receptors

\begin{tabular}{|c|c|c|c|}
\hline Cell Surface Receptors & Novel Agent & Description & Status \\
\hline \multirow[t]{2}{*}{ IL-6 } & Anti-IL-6 mAbs & & Phase I \\
\hline & Sant-7 & IL-6 superantagonist & Preclinical \\
\hline \multirow[t]{4}{*}{ bFGF } & SU5402 & $\begin{array}{l}\text { Small molecule tyrosine kinase } \\
\text { inhibitors }\end{array}$ & Preclinical \\
\hline & PD173074 & & \\
\hline & PKC412 & & \\
\hline & PRO-001 & Anti-FGFR3 antibody & Preclinical \\
\hline IGF-1 & NVP-ADW742 & IGFR tyrosine kinase inhibitor & Preclinical \\
\hline \multirow[t]{4}{*}{ VEGF } & Avastin/bevacizumab & Anti-VEGF antibody & $\begin{array}{l}\text { FDA approved for } \\
\text { metastatic colon } \\
\text { cancer }\end{array}$ \\
\hline & PTK787 & VEGFR tyrosine kinase inhibitor & Phase I \\
\hline & SU5416 & & Phase II \\
\hline & GW654652 & & Preclinical \\
\hline \multirow[t]{2}{*}{ TNF family } & TRAIL/Apo2L & & Preclinical \\
\hline & SGN-40 & CD40 ligand & Preclinical \\
\hline TGF- $\beta$ & SD-208 & TGF- $\beta R$ tyrosine kinase inhibitor & Preclinical \\
\hline CD20 & Rituximab & Anti-CD20 antibody & Preclinical \\
\hline
\end{tabular}

chromosomal translocations result in the overexpression of several important oncogenes, including MMSET and FGFR3 (at 4p16), CCN D3 (at 6p21), CCB D1 (at 11q13), c-MAF (at 16q13), and MAFB (at 20q11)[6,7,8,9,10]. In particular, as high as $40 \%$ of MM cells have at least one of these mutations[11]. Eventually, malignant clones carrying these mutations progress and undergo further genetic insults leading to advanced disease. In particular, mutations in c-myc, N-Ras, and K-ras oncogenes have been implicated in later stages of myeloma pathogenesis, and these will be discussed later in this review.

Environmental factors play an equally important role in the progression of disease. The malignant plasma cells home to the bone marrow where subsequent interactions serve to facilitate the development and progression of disease. In particular, advances in understanding myeloma biology have implicated the phosphatidylinositol-3 kinase (PI3K)/Akt (also known as protein kinase B [PKB]), mitogen-activated 
protein kinase (MAPK), Janus kinase 2 (JAK2)/signal transducers and activators of transcription (STAT) 3 , I- $\kappa \mathrm{B}$ kinase $(\mathrm{IKK}) /$ nuclear factor $\kappa \mathrm{B}(\mathrm{NF}-\kappa \mathrm{B})$, and Hsp90 signaling pathways as key culprits in the pathogenesis of disease (Fig. 1).

(IL-6, IGF-1, VEGF, TNF $\alpha$, TGF $\beta$, bFGF)

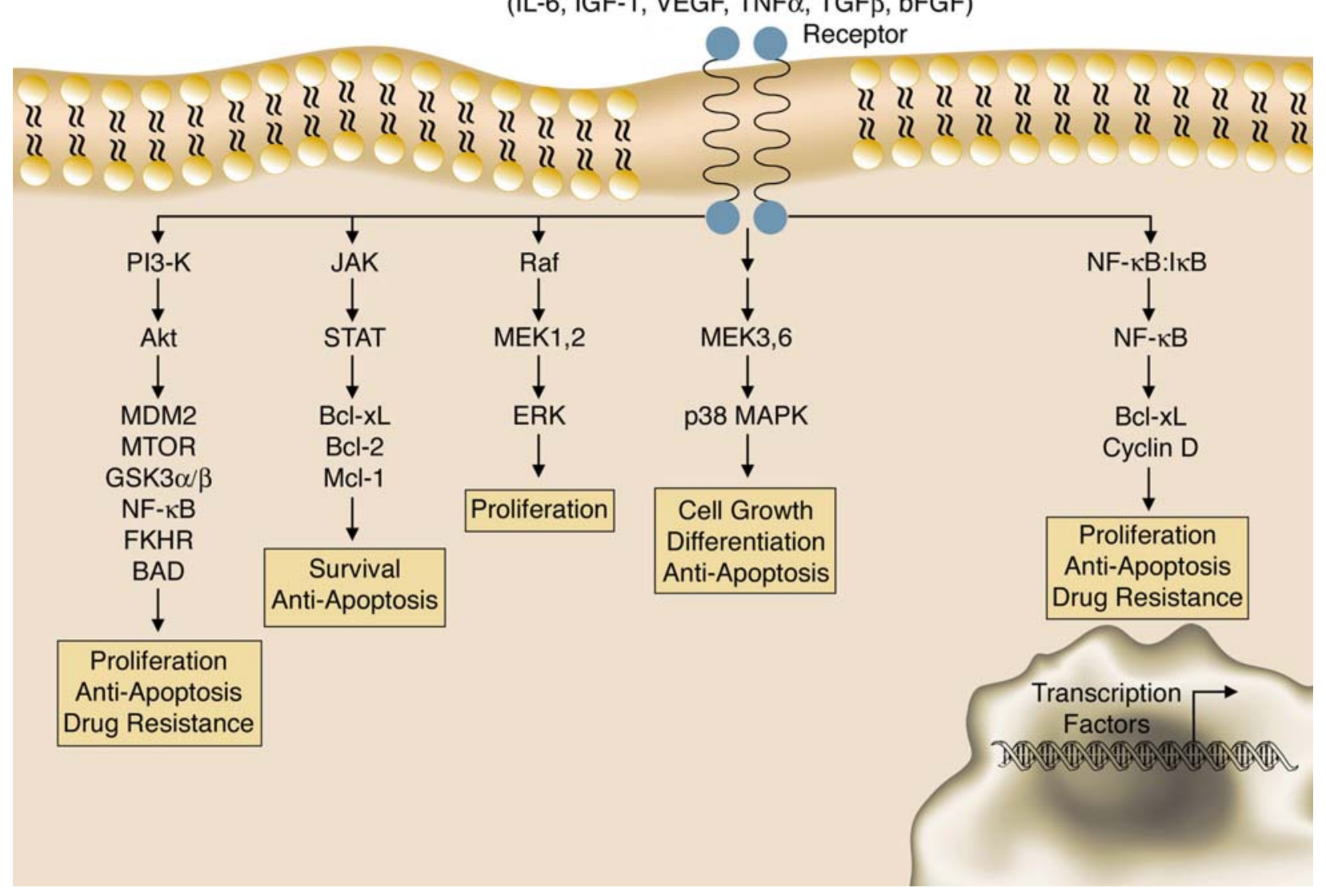

FIGURE 1. Simplified overview of intracellular signaling pathways.

The important role of the bone marrow microenvironment cannot be emphasized enough in the development of disease. There is now a large body of data describing how the bone marrow microenvironment, a complex landscape composed of hematopoietic stem cells, extracellular matrix (ECM) proteins, bone marrow stromal (BMSC) and endothelial cells, fibroblasts, osteoclasts, and osteoblasts, helps to facilitate MM cell growth, survival, and migration as well as mediate the development of drug resistance[12,13,14].

\section{NOVEL AGENTS TARGETING INTRACELLULAR SIGNALING PATHWAYS}

Many of the agents currently being evaluated in myeloma exert their effects on a broad range of pathways, and for many drugs, the exact mechanisms of action are still being delineated. For the purposes of this review, the novel agents will be loosely grouped based on the pathways that appear to be most significant. 


\section{Targeting the PI3KIAkt Pathway}

The phosphatidylinositol-3 kinase (PI3K) signaling cascade is one of two major pathways that are activated by receptor tyrosine kinases. PI3K is composed of regulatory and catalytic subunits, which when activated, catalyze and further activate a wide range of downstream targets, most notably the serine/threonine protein kinase Akt (PKB). Akt has emerged as an important player in mediating tumor progression. It has a multifaceted role in cell survival, including sequestering the FOXO family of Forkhead transcription factors from activating their proapoptotic targets, such as FasL and Bim[15]; phosphorylating and thus sequestering $\mathrm{Bad}$, a proapoptotic $\mathrm{Bcl}-2$ family member, from the

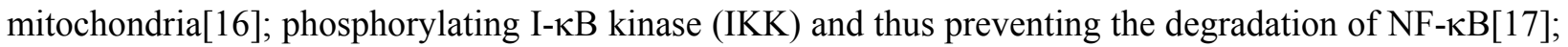
and reciprocal regulation of the tumor suppressor gene, p53[18]. In addition, Akt regulates cell proliferation and growth by targeting the activity of glycogen synthase kinase $\beta$ and preventing cyclin D1 degradation[19] as well as targeting mTOR (mammalian target of rapamycin). mTOR, also known as rapamycin-associated protein (FRAP), is a serine/threonine kinase that serves as a molecular sensor that regulates cell growth and proliferation in response to nutrients, growth factors, and insulin[20,21]. mTOR-dependent phosphorylation of several downstream molecules is critical for the cap-dependent translation of cell cycle proteins and progression from G1 to S phase[22].

Recently, there has been exciting evidence suggesting that the PI3K/Akt pathway is an important target in antimyeloma therapy. Akt is constitutively activated in patient myeloma cells, but interestingly, not in nonmalignant cells from the same patient[23]. Perhaps most importantly, many of the key growth factors in myeloma, such as IL-6, VEGF, and IGF-1, are ligands for tyrosine kinase receptors, which then activate the PI3K/Akt pathway. IL-6, the major myeloma growth factor, has been shown to induce phosphorylation of Akt and its downstream targets in a time- and dose-dependent manner. Furthermore, IL-6 overcomes dexamethasone-induced apoptosis via activation of PI3K/Akt[24].

Given the importance of the PI3K/Akt pathway in tumorigenesis, numerous drugs are currently under evaluation for a variety of malignancies[25]. In MM, three agents are currently being evaluated.

\section{Perifosine}

Perifosine, an orally active, alkyl-phosphocholine compound, belongs to a novel class of antitumor drugs that effect membrane permeability, phospholipid metabolism, and mitogenic signal transduction[26]. Importantly, perifosine has been shown to inhibit Akt activation without affecting the activity of PI3K or phosphoinositide-dependent kinase 1 (PDK1)[27]. It has been shown in vitro to induce p21 ${ }^{\text {WAF1 }}$ expression and cell cycle arrest in head and neck squamous cell carcinoma[28], and two phase I studies have been completed in solid tumors[29].

In MM, Hideshima and colleagues found that perifosine inhibits Akt activation, induces $\mathrm{JNK} /$ caspase-dependent apoptosis in conventional therapy-resistant and -sensitive MM cell lines, overcomes the survival advantages of interaction between MM cell and BMSCs, and is not cytotoxic to peripheral blood mononuclear cells. Furthermore, it has significant antitumor effects in a murine MM mouse model[30]. Finally, given its pleotropic effects and based on initial preclinical studies, perifosine may have a valuable role in combination with other novel and standard therapies. When used in combination with standard therapies, such as dexamethasone, melphalan, and doxorubicin, perifosine augmented MM cytotoxicity in vitro. Interestingly, the proteasome inhibitor, bortezomib, was found to activate Akt and combination with perifosine blocked this activation. This finding offers preliminary evidence that combination with perifosine may overcome clinical resistance to bortezomib[30]. Phase II clinical trials are currently underway to evaluate the clinical uses for perifosine $+/$ - dexamethasone as well as examining perifosine in combination with bortezomib in patients with relapsed or refractory MM. 


\section{Rapamycin and Its Analogues: CCI-779, RAD-001}

Rapamycin and its more soluble derivatives CCI-779 and RAD-001 are mTOR inhibitors. Rapamycin binds to its receptor, FK506 binding protein 12, which then complexes with mTOR to block its activity effectively[31,32]. Several studies have examined mTOR inhibitors' ability to not only induce cell cycle arrest, but induce apoptosis[32]. In particular, studies have found that both rapamycin and CCI-779 augment dexamethasone-induced apoptosis in vitro and in vivo[22]. mTOR inhibitors have been examined in phase II clinical trials for solid tumors, and are currently in phase II trials for myeloma[33]. In addition, Phase II trials of combination of CCI-779 with bortezomib are underway.

\section{Enzastaurin}

The protein kinase C (PKC) family of serine/threonine kinases has a myriad of targets that are involved in a broad range of cellular events, such as proliferation, growth, and transcription. Recent preclinical studies suggest that the PKC $\beta$ inhibitor, enzastaurin (LY317615), can overcome growth advantages conferred by BMSCs and acts on MM cell lines that are both sensitive and resistant to conventional therapies by inhibiting cell growth, survival, and migration[34]. Furthermore, enzastaurin may exert its apoptotic effects via inhibition of Akt[34,35]. A phase II trial of enzastaurin will be available for patients with relapsed/refractory MM.

\section{The MAPK Signaling Pathways}

There are three major groups of mitogen-activated protein kinases (MAPKs): the extracellular signalregulated kinase (ERK) family, the p38 MAPK family, and the c-Jun $\mathrm{NH}_{2}$-terminal kinase (JNK) family. As their name implies, these families of serine/threonine kinases are activated by growth factors and other stimuli, and they also participate in the production and secretion of cytokines. The MAPKs are intimately involved in the regulation of key cellular processes, such as cell cycle progression, growth, differentiation, and apoptosis; as such, they are often implicated in malignant transformation and tumor progression[36].

\section{Targeting the Ras/Raf/MEK/ERK Family}

Numerous studies have shown that cytokine-induced cell proliferation is predominantly mediated through the ERK family of MAPKs[24,37,38,39,40], which are a part of a large cascade of proto-oncogenes including the upstream activators, Ras and Raf. In myeloma, 30-40\% of patients have mutated Ras. NRas and K-Ras mutations, which lead to constitutively active Ras, have been observed in the malignant cells of patients with advanced stage disease[41,42]. While IL-6-dependent proliferation of MM cells is known to be dependent on ERK activation[43,44], interestingly, the inhibition of ERK in an IL-6independent MM cell line with constitutively active Ras did not block cell proliferation. These data suggest that Ras can activate ERK-independent pathways[45].

Farnesyltransferase Inhibitor: Tipifarnib/R115777, L744832, Manumycin, BMS-214662, and Lonafarnib/SCH66336

There has been great interest in the use of farnesyltransferase inhibitors (FTIs) to target Ras in myeloma. Farnesyltransferase catalyzes the first step in post-translational modification of Ras, which allows the Ras protein to migrate to the cell membrane, where it exerts its activity. Several agents, including L744832[46], 
manumycin[47], BMS-214662[48], lonafarnib/SCH66336[49], and tipifarnib/R115777[50,51,52], have been shown to inhibit cell growth and survival in both drug-resistant and -senstitive MM cell lines. Of note, lonafarnib has been shown to work synergistically with bortezomib to enhance MM cell death. Interestingly, this synergistic response was associated with caspase cleavage as well as decreased phosphorylation of Akt, suggesting that FTIs may be promising agents in combination with proteasome inhibitors[49]. A phase II clinical trial of tipifarnib/R115777 in patients with advanced MM found that it was well tolerated and induced stabilization of disease[50].

\section{Targeting the p38 MAPK Pathway}

p38 MAPK is a serine/threonine kinase involved in stress responses to environmental stressors such as inflammatory cytokines, UV light, and osmotic shock. There are four known splice variants of the p38 MAPKs, and p38 $\alpha$ has been found to have major documented effects on cell growth, differentiation, and apoptosis[53].

\section{SCIO-469}

SCIO-469, a selective p38 MAPK inhibitor, has been studied in phase I/II trials for rheumatoid arthritis. In myeloma, it decreases proliferation of MM cells and blocks IL-6 and VEGF secretion from BMSCs[37]. In addition, SCIO-469 is being considered in combination with the proteasome inhibitor, bortezomib, because while bortezomib achieves excellent response in 35\% of relapsed/refractory MM patients, there is a substantial population that are either unresponsive or develop resistance. SCIO-469 has been shown to augment the cytotoxicity of bortezomib in vitro and in vivo, in part due to down-regulation of Hsp27, a molecule whose overexpression has been associated with dexamethasone resistance[54,55].

\section{Targeting the MAPK/JNK Pathway}

JNK, often found to be activated after chemotherapy, has been shown to exhibit both oncogene[56] and tumor-suppressor gene activities[57]. The exact role of JNK in myeloma is unclear; JNK inactivation appears to be one mechanism by which IL-6 protects MM cells from Fas-induced apoptosis[39,58], and the proteasome inhibitor, bortezomib, induces JNK activation during MM cell apoptosis[59,60]. The JNK1/2 specific inhibitor, SP600125, has been shown to induce G2/M arrest in MM cells and, interestingly, activates NF- $\mathrm{KB}$ in a time- and dose-dependent fashion[59].

\section{Aplidin/Plitidepsin}

Aplidin, a naturally occurring, cyclic depsipeptide isolated from the marine tunicate Aplidium albicans, exhibits very promising antitumor effects both in vitro and in vivo, and it is now in phase II clinical trials for a variety of solid and hematologic tumors. The exact mechanisms of action are unclear, but aplidinmediated cytotoxicity has been shown to be dependent on sustained activation of JNK[61,62,63]. It exhibits strong apoptotic effects on MM cell lines and patient cells by triggering JNK, Fas, and mitochondrial-mediated signaling pathways[64].

Lopez-Martin and colleagues reported in abstract form that in Phase I and II trials of 215 and 112 patients, respectively, Aplidin was generally well tolerated with major dose limiting toxicity being adverse musculoskeletal events including increased CPK, myalgia and weakness [65]. Tumor shrinkage and long-lasting disease stabilization were reported in patients with colorectal, renal, neuroendocrine, 
lung, and head and neck cancer as well as melanoma and non-Hodgkin's lymphoma. Based on these initial results, phase II trials are currently underway in myeloma.

\section{Targeting the NF-кB Pathway}

Nuclear factor $\kappa \mathrm{B}(\mathrm{NF}-\kappa \mathrm{B})$, a small class of Rel family transcription factors, has emerged as a key player in the pathogenesis of myeloma. It plays a critical role in regulating many cellular responses, including immunity, inflammation, proliferation, survival, and angiogenesis[66,67,68]. Inactive NF-кB complexes with its inhibitor, I $\kappa \mathrm{B} \alpha$, and remains sequestered in the cytosol. A variety of stimuli trigger the

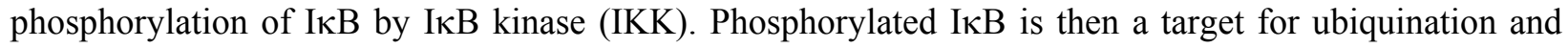
proteasome-mediated degradation, which in turn releases $\mathrm{NF}-\kappa \mathrm{B}$ to translocate from the cytosol to the nucleus. Once in the nucleus, NF- $\kappa \mathrm{B}$ stimulates transcription of numerous cytokines, chemokines, and cell adhesion molecules[69]. NF- $\kappa \mathrm{B}$ is constitutively activated in numerous hematologic malignancies, including myeloma[70], and several agents have been examined to target the NF- $\mathrm{KB}$ pathway directly and indirectly.

\section{PS-1145}

PS-1145, a selective IKK inhibitor, was shown to inhibit IL-6 production from BMSCs cocultured with MM cells; however, compared to the complete cell proliferation blockade observed with bortezomib treatment, PS-1145 only partially inhibits MM cell proliferation in vitro, suggesting that there other therapeutic targets of proteasome inhibition[71,72,73].

\section{Other Agents}

Dexamethasone has been shown to down-regulate NF- $\mathrm{BB}$ activity, and conversely, constitutive activation of NF- $\kappa \mathrm{B}$ mediates dexamethasone resistance in MM cells[74]. Thalidomide has also been shown to down-regulate NF- $\kappa \mathrm{B}$ activity[75]. Finally, one of the most exciting new classes of agents in myeloma therapy is the proteasome inhibitor, which by preventing the degradation of NF- $\kappa \mathrm{B}$ inhibitor, I $\mathrm{B}$, effectively inactivates $\mathrm{NF}-\mathrm{\kappa B}$ and prevents its promalignancy effects[76]. The prototype proteasome inhibitor, bortezomib, and its newer analogue, will be extensively discussed later in this review. Importantly, NF- $\kappa$ B blockade accounts for only part of bortezomib's antimyeloma effects.

\section{Targeting the JAKISTAT Pathway}

The Janus kinase (JAK) family of tyrosine kinases plays a crucial role in cytokine signaling by phosphorylating the intracellular domains of cytokine receptors and recruiting downstream factors, such as STATs (signal transducers and activators of transcription), which then migrate to the nucleus and upregulate gene transcription. STAT3 is of particular relevance in myeloma and other malignancies because its binding elements have been found on the promoters of several antiapoptotic genes, including Mcl-1, Bcl-2, and Bcl-xL[77]. Importantly, IL-6 binding to its receptor and the subsequent JAK/STAT3 activation is associated with myeloma cell survival[43,78] likely secondary to up-regulation of Mcl-1[79] and drug resistance[80]. 


\section{Azaspirane: Atiprimod}

Azaspiranes are compounds that have previously been studied in preclinical and clinical trials as antiinflammatory agents for rheumatic diseases. While the exact mechanisms of action remain unclear, atiprimod, an orally bioavailable azaspirane, has been found to down-regulate the expression of adhesion molecules and cytokines, such as IL-6, TNF- $\alpha$, and IL-2[81]. In myeloma, it has shown very promising in vitro antimyeloma effects including inducing apoptosis via down-regulation of phosphorylated STAT3 and its antiapoptotic targets, Mcl-1 and Bcl-2; inhibiting cell proliferation; and decreasing NF- $\mathrm{KB}$ activation. Importantly, the effects of atiprimod could not be overcome by the survival advantages conferred by IL-6, VEGF, or adherence of MM cells to BMSC[82]. Furthermore, azaspirane has been shown in a SCID-hu mouse model to inhibit tumor growth, further suggesting that it may have a beneficial role in patient therapy[83]. Currently, phase I/II trials are underway examining atiprimod in refractory or relapsed myeloma.

\section{Triggering Apoptotic Pathways}

Almost all the therapies being evaluated in the treatment of myeloma exhibit some in vitro apoptotic effects, and many of these also have in vivo effects as well. The details of the intrinsic, extrinsic, and mitochondrial apoptotic pathways are beyond the scope of this review. In this section, the preclinical data for several novel therapies that have been shown to induce apoptosis in myeloma will be summarized, most notably, arsenic trioxide, LPAAT inhibitors, 2-methoxyestradiol, and others.

\section{Arsenic Trioxide $\left(\mathrm{As}_{2} \mathrm{O}_{3}\right)$}

Arsenic trioxide, currently being used in the clinic for treatment of relapsed/refractory, acute, promyelocytic leukemia, has shown promise in the treatment of myeloma as well[84]. In vitro studies have suggested that it works via several different pathways. Most notably, it has been shown to downregulate $\mathrm{Bcl}-2$, induce caspase-9 cleavage, and induce apoptosis in both drug-senstitive and -resistant MM cell lines[85]. Furthermore, it has been shown to inhibit both the JAK/STAT3 and NF-кB signaling pathways as well as decreasing paracrine IL-6 secretion from BMSCs[12,86]. It has also been found to up-regulate the expression of TRAIL (tumor necrosis factor-related apoptosis-inducing ligands) receptors, suggesting that combination with TRAIL may be of benefit[87].

\section{LPAAT Inhibitor}

Lysophosphatidic acid acyltransferase (LPAAT) catalyzes the conversion of lysophosphatidic acid to phosphatidic acid, a phospholipid involved in lipid biosynthesis and signal transduction. LPAAT- $\beta$ inhibitors, in particular CT-32176 (the most potent), have been shown in myeloma cell lines to induce apoptosis via caspase cleavage and JNK signaling. Importantly, the antimyeloma effects of LPAAT- $\beta$ inhibitors overcome growth advantages conferred by MM cell-BMSC adhesion and can overcome resistance to conventional therapies, such as dexamethasone and melphalan[88], as well as novel therapies, such as bortezomib[89], in vitro. 


\section{2-Methoxyestradiol}

2-Methoxyestradiol (2-ME2), an endogenous derivative of estradiol, was initially found to have significant antileukemic actions in vitro and in vivo. It has been found to induce apoptosis via the mitochondrial release of Smac protein and cytochrome $\mathrm{C}$, which results in the inactivation of IAP (inhibitors of apoptosis) proteins followed by activation of the caspase cascade[90]. Furthermore, it decreases VEGF and IL-6 secretion from BMSC, suggesting antiangiogenic potential. In addition, in vitro and in vivo data indicate that 2-ME2 is effective in MM cells resistant to melphalan and doxorubicin[91].

\section{Bcl-2 Inhibitor: ABT-737}

The Bcl-2 family of proteins is a key player in the regulation of mitochondria-dependent apoptosis. Overexpression of Bcl-2 and Bcl-xL has been noted in numerous malignancies, including MM, and Bcl-2 has also been implicated in the development of drug resistance and disease progression[92,93]. The small molecule Bcl-2 inhibitor, ABT-737, binds specifically to Bcl-2, Bcl-xL, and Bcl-w, and inhibits their proapoptotic effects by augmenting the effects of death signals[94].

Early results for ABT-737 have been very promising in solid tumors[94]. In myeloma, ABT-737 has been shown to induce apoptosis in MM cell lines and patient cells. Furthermore, it is cytotoxic in MM cells that are resistant to conventional therapies, and it enhances the antimyeloma effects of bortezomib and melphalan[93,95].

\section{Others}

Many novel, apoptotic agents are currently in the early stages of evaluation in myeloma. Some of these include triterpenoids (CDDO-Im)[96], inosine monophosphate dehydrogenase inhibitors (VX-944)[97], Smac mimetics (PK1195), sphingosine monophosphate inhibitors (FTY720)[98], and etodolac (SDX101)[99].

\section{Targeting Multiple Pathways: Thalidomide and Its Derivatives, Imids}

Thalidomide, a glutamic acid derivative, was first used in myeloma based on its known antiangiogenic effects. However, it is now known that thalidomide and its more potent derivatives exert their activities through a broad spectrum of effects not limited to angiogenesis. In fact, microvessel density in the bone marrow and plasma VEGF and bFGF levels are not significantly different between patients treated with or without thalidomide[100,101]. Its other mechanisms of action include, but are not limited to, directly inhibiting MM cell growth and survival, preventing MM cell-BMSC adhesion, inhibiting secretion of cytokines needed for survival and growth, and promoting antimyeloma immune responses. The full details of the many cellular effects of thalidomide are beyond the scope of this review; however, several activities are particularly important in combating myeloma. Thalidomide blocks the secretion of potent myeloma growth factors (IL-6 and VEGF), induces apoptosis via caspase-8 activation, blocks NF- $\mathrm{kB}$ activity, and inhibits IL-6-induced MAPK pathways[12,102,103,104,105,106].

Thalidomide derivatives, such as lenalidomide (Revlimid)[107,108] and CC-4047 (Actimid) $[109,110]$, are two of the most promising, second-generation thalidomide derivatives. Both can be administered orally and although they exert many similar biologic effects as thalidomide, both agents are much more potent and have significantly fewer toxic side effects than their predecessor[111,112,113]. Clinical trials are currently underway for both drugs and will be discussed later in this review. 


\section{NOVEL AGENTS TARGETING CELL MAINTENANCE PROCESSES}

\section{Targeting Protein Degradation via Proteasomes and Aggresomes}

\section{The Proteasome}

The ubiquitin-26S proteasome pathway, which regulates the turnover of a vast number of intracellular proteins, has become an exciting target in a variety of malignancies, most notably MM. Normally, proteins that are tagged with multiple, ubiquitin molecules enter the $26 \mathrm{~S}$ proteasome for subsequent degradation. The proper functioning of this system is crucial for cell cycle regulation, gene transcription, and signal transduction. One of the proteins degraded by the $26 \mathrm{~S}$ proteasome, I $\mathrm{KB} \alpha$, is an inhibitory protein that is bound to NF- $\mathrm{BB}$ and prevents NF- $\kappa \mathrm{B}$ translocation to the nucleus. As mentioned earlier, once in the nucleus, NF- $\kappa \mathrm{B}$ promotes the transcription of numerous genes involved in cell survival, proliferation, and drug resistance. Inhibition of the proteasome effectively increases the presence of IкB $\alpha$ and prevents NF- $\mathrm{KB}$ release to the nucleus.

\section{Bortezomib}

The prototype 26S proteasome inhibitor, bortezomib (Velcade, PS-341), selectively binds to the catalytic domain of the proteasome and prevents its activity. Predictably, bortezomib exhibited exciting antimyeloma effects associated with inhibition of NF- $\kappa B$ activity[72,76,114,115,116]; however, it should be noted that subsequent in vitro studies have revealed numerous other antimyeloma effects independent of the NF- $\mathrm{BB}$ pathway. Thus, the complete molecular mechanisms of its activity remain undefined[117]. It is now known to regulate cell cycle proteins, and targets both the intrinsic and extrinsic apoptotic pathways via caspase- 9 and caspase- 8 , respectively.

\section{NPI-0052}

Recently, another proteasome inhibitor, NPI-0052, with a different chemical structure, toxicity profile, and mechanism of action, has been studied. Like bortezomib, NPI-0052 also inhibits NF- $\mathrm{BB}$, blocks proteasome activity, and induces apoptosis in MM cells, but not BMSCs; furthermore, it is active at lower concentrations than bortezomib and can be orally administered. Interestingly, NPI-0052-mediated apoptosis appears to be predominately through the caspase- 8 cell death cascade. This difference between bortezomib and NPI-0052 may, in part, explain the finding that a combination of the two proteasome inhibitors had a synergistic effect on cytotoxicity[118].

\section{The Aggresome}

There are several pathways through which misfolded or aggregated proteins are processed in a cell, including refolding via molecular chaperones or degradation via proteasomes. Recently, there has been evidence suggesting a third pathway of protein disposal involving the sequestration of aggregated proteins into spherical aggresomes for further processing, most commonly, lysosomal degradation. Notably, aggresomes are not simply static depositories for misfolded proteins, they also recruit chaperones and proteasomes to help in the clearance of the misfolded proteins. In light of the success of proteasome inhibition, it is possible that other means of cell protein catabolism may also be good therapeutic targets. 


\section{Tubacin}

Histone deacetylase 6 (HDAC6) plays an essential role in aggresome activity by binding polyubiquinated proteins to the dynein motors needed for recruitment to aggresomes[119]. Tubacin, a small molecule that triggers acetylation of $\alpha$-tubulin, directly inhibits HDAC6 to block aggresome activity. In a study by Hideshima and colleagues, tubacin was found to inhibit interaction with HDAC6. Furthermore, when used in combination with bortezomib, it induces synergistic accumulation of polyubiquinated proteins, increases cytotoxicity to MM cells, as well as decreases paracrine (BMSC)-induced cell growth[120].

\section{Targeting Transcription}

Histones are positively charged proteins that attract and organize negatively charged DNA into nucleosomes. As such, their regulation by the opposing actions of histone acyltransferases and histone deacetylases (HDAC) plays a key role in gene expression, cell differentiation, and survival.

\section{HDAC Inhibitors: SAHA, NVP-LAQ824, and NVP-LBH589}

In MM, several novel HDAC inhibitors, including suberoylanilide hydroxamic acid (SAHA), NVPLAQ824, and NVP-LBH589, are currently being evaluated. SAHA, in particular, has been shown to have pleiotropic antimyeloma effects; most notably, it induces apoptosis in MM cell lines and patient cells that are both sensitive and resistant to conventional therapies, and it sensitizes MM cells to other chemotherapies in vitro[121,122]. A phase I study of SAHA in relapsed/refractory myeloma is currently underway.

\section{Targeting Protein Chaperoning}

Heat shock proteins (HSP) are a class of molecular chaperones that, under normal conditions, facilitate proper protein folding and regulate the turnover of important cell growth and survival proteins. When under conditions of environmental stress, HSP expression increases in an adaptive means to maintain cell homeostasis and enhance cell survival. Elevated levels of HSPs have long been noted in many malignancies, and these chaperones seem to help protect malignant cells from stressful microenvironments as well as from otherwise lethal mutations within the tumor cells themselves. HSP90 plays a particularly important role in oncogenesis because many of its protein substrates (such as receptor tyrosine kinases, serine/threonine kinases, telomerase, Akt, HIF1 $\alpha$ ) are signal transducers that regulate cell growth, proliferation, and survival[123,124].

\section{HSP90 Inhibitor: 17AAG}

Several HSP90 inhibitors have been tested in preclinical studies; however, only one, 17AAG, a geldanamycin derivative that binds to the N-terminal ATP-binding pocket of HSP90, has been studied in vivo and in clinical trials[125]. In myeloma, 17AAG induces potent apoptosis in drug-sensitive and -resistant cells in vitro. It has also been reported to act synergistically with bortezomib[126] and HDAC inhibitors[127]. Phase I trials are currently underway for 17AAG as a single agent in myeloma and also in combination with trastuzumab (Herceptin). Other HSP90 inhibitors with a more tolerable profile than 17AAG, such as KOS-953[128,129,130] and IPI-504[131,132,133], are being tested in phase I and II clinical trials in MM. 


\section{Targeting Mitosis}

Telomeres are nucleoprotein complexes that protect against degradation and erosion of chromosomes during replication cycles and serve to protect chromosome ends, which may otherwise be mistaken for double strand breaks, from fusion by repair mechanisms[134]. During each round of replication, the telomeres are eroded, and critical shortening of telomeres results in irreversible mitotic inhibition and cell death. Cells, thus, rely on the activity of telomerase, a reverse transcriptase, to lengthen and stabilize the telomeres, and in malignant cells, telomerase activity helps to confer immortality. High telomerase expression has been noted in up to $95 \%$ of human cancers $[135,136]$.

\section{Telomerase Inhibitor: GRN163}

Telomerase inhibitors, such as GRN163[137], an oligonucleotide against human telomerase RNA component, and Telomestatin (3533-SV4)[138], an intercalating agent specific for telomeric sequences, have been found to shorten telomere length in MM cells and induce apoptotic cell death and growth inhibition.

\section{NOVEL AGENTS TARGETING CELL SURFACE RECEPTORS}

\section{Targeting IL-6}

IL-6 is known to be a major growth and survival signal in MM cells whose effects are both autocrine and paracrine[139,140]. Serum IL-6 levels correlate with the proliferative fraction of MM cells, and high levels are associated with a poor prognosis[141]. IL-6 is secreted by both tumor cells and BMSCs, and secretion is augmented by direct binding between tumor cells and BMSCs as well as by additional cytokines, such as TNF $\alpha$, VEGF, and TGF- $\beta$, within the BM microenvironment[142].

IL-6 activates several major signaling cascades, including the Ras/Raf/MEK/ERK, the JAK2/STAT3, and the PI3K/Akt cascades, which mediate cell proliferation, survival, and drug resistance, respectively[12]. The initial step in the activation of these pathways involves the binding of IL-6 to its low-affinity receptor (IL-6R $\alpha / \mathrm{gp} 80$ ) and the subsequent homodimerization of signal transducer, gp130[143]. Notably, gp130 has no IL-6 binding capacity by itself, but activation by the IL-6/IL-6R complex results in homodimerization and phosphorylation of tyrosine residues in the intracellular domain of gp130 by the JAK family of enzymes[144,145].

\section{Anti-IL-6 Monoclonal Antibody}

Treatments targeting IL-6 have focused on monoclonal antibodies (mAbs) to IL-6 and IL-6R, and, more recently, the IL-6 superantagonist, Sant7. Anti-IL-6 mAbs, initially studied as promising therapies for rheumatoid arthritis and lupus, have been shown to have antitumor effects in animal and preclinical human studies[146,147]. In myeloma, anti-IL-6 mAbs have cytostatic effects on tumor cells in vitro as well as transient, antimyeloma effects in both animal models and human preclinical trials[148,149]. In particular, Bataille and colleagues found in a clinical trial that treatment with anti-IL-6 mAbs had antimyeloma effects, such as reduction of myeloma cell production and inhibition of $\mathrm{C}$-reactive protein synthesis, an acute phase reactant synthesized in the liver in response to IL-6; however, none of the patients achieved remission or improvement as assessed by standard clinical criteria[150]. 


\section{IL-6 Superantagonist: Sant7}

Recently, much interest has turned to IL-6 superantagonists, which have a high affinity for IL-6R, but no bioactivity[151]. The most potent of these superantagonists, Sant7, has been shown to inhibit cell proliferation and induce apoptosis in IL-6-dependent myeloma cell lines[152]. Importantly, it has shown promise in combination with dexamethasone, one of the most active drugs in the treatment of MM. Numerous studies have implicated IL-6 production in the development of MM cell resistance to dexamethasone[104,153,154]. Sant7 overcomes resistance to dexamethasone in MM cell lines as well as potentiates the cytotoxic effects of dexamethasone and zoledronic acid[155,156]. Importantly, when evaluated in a SCID-hu in vivo mouse model of myeloma, Sant7 also significantly potentiates the antimyeloma effects of dexamethasone without significantly affecting CD34+ hematopoeitic progenitor cell growth[151]. Taken together, Sant7 is a promising therapeutic agent when used in combination with glucocorticoids, such as dexamethasone.

\section{Targeting Fibroblast Growth Factor}

FGF-2 (basic FGF, bFGF) is a potent angiogenic cytokine secreted by MM cells and, to a lesser extent, BMSCs. Increased levels of FGF-2 are seen in serum, bone marrow, and plasma cell lysates of MM patients. Studies have demonstrated that serum FGF-2 levels decreased significantly after successful MM treatment $[157,158,159]$. Furthermore, paracrine interactions between FGF-2 and IL-6 contribute to increased neovascularization as well as MM cell proliferation. Notably, IL-6 enhances FGF-2 expression and secretion by MM cell lines and patient cells, and stimulation of BMSCs with FGF-2 induces a timeand dose-dependent increase in IL-6 secretion[157].

The signaling of FGF-2 is mediated by binding to a family of four distinct tyrosine kinase receptors (FGFR1-FGFR4), all of which are present on patient BMSCs and MM cells. Activation of FGFRs transduces signals through MAPK and PI3K pathways. Dysregulation of fibroblast growth factor receptor 3 (FGFR3) by the $t(4 ; 14)$ translocation is known to confer a poorer prognosis and is a primary event in $15-20 \%$ of MM cases[160,161]. Thus, there has been interest in targeting FGFR3 by both selective small molecule tyrosine kinase inhibitors and monoclonal antibodies.

\section{Small Molecule Tyrosine Kinase Inhibitors: SU5402, PD173074, PKC412}

Small molecule tyrosine kinase inhibitors, such as SU5402, PD173074, and PKC412, decrease viability and induce tumor cell growth arrest in human MM t(4,14) cell lines[162,163,164]. However, these agents may be limited by cross-reactivity with other receptor kinases.

\section{Anti-FGFR3 Antibody: PRO-001}

PRO-001, an anti-FGFR3 antibody, has a high affinity for FGFR3, decreases proliferation, and induces apoptosis in $\mathrm{t}(4: 14) \mathrm{MM}$ cells[165]. These preclinical studies suggest a role for FGFR3 inhibitors in MM patients with the $\mathrm{t}(4,14)$ translocation.

\section{Targeting Insulin-Like Growth Factor-1}

IGF-1, a critical cytokine in the pathogenesis of MM, is known to have a plethora of downstream effects, including the activation of the MAPK/ERK and PI3K/Akt signaling pathways[166]. In recent studies, it has been shown to act synergistically with IL-6 and protects against dexamethasone-induced apoptosis[13,167,168]. Furthermore, IGF-1 mediates MM cell growth and survival in MM cells both in 
vitro[168,169] and in vivo[170]. IGF-1 is a ligand for IGF receptor (IGF-1R), a tyrosine kinase signaling molecule, which is universally expressed on hematologic and solid tumor cell lines as well as patient MM cells[170].

\section{IGFR Tyrosine Kinase Inhibitor: NVP-ADW742}

Given the pleiotropic effects of IGF-1, targeted strategies against IGF-1R may have important clinical relevance [167]. A study by Mitsiades and colleagues showed that IGF-1R inhibition by the smallmolecule IGF-1R tyrosine kinase inhibitor, NVP-ADW742, induced cytotoxicity in MM cells and was active even in cell lines resistant to conventional treatments, such as dexamethasone. Importantly, systemic administration of NVP-ADW742 suppressed tumor growth, prolonged survival, and potentiated the effects of other chemotherapies in vivo[170].

\section{Targeting Vascular Endothelial Growth Factor}

VEGF, a potent angiogenic factor, is produced both by MM cells and BMSCs[171,172]. In addition to neovascularization, it has pleiotropic effects in the pathogenesis of MM, including aiding MM cell migration via PI3K-dependent $\mathrm{PKC} \alpha$ activation, increasing proliferation and resistance to apoptotic signals via the up-regulation of Mcl-1, and augmenting the secretion of IL-6 by the BMSC[172,173,174,175]. The VEGF ligand exerts its effect after binding to its high-affinity tyrosine kinase receptor molecule, Flt-1, which is expressed on both MM patient cells as well as cell lines[171,172]. VEGF-triggered phosphorylation of Flt-1 activates the MAPK signaling pathway and ultimately leads to increased proliferation[12].

\section{Bevacizumab (Avastin)}

Agents targeting VEGF have shown great promise in the treatment of other malignancies. Most notably, the humanized monoclonal antibody against VEGF, bevacizumab (Avastin), was recently FDA approved as first-line therapy for metastatic colon cancer when given in combination with 5-FU[176]. Given the important role that VEGF plays in the progression of myeloma, these agents are now being studied as potential antimyeloma therapies. Bevacizumab is being studied in relapsed or refractory MM (with or without thalidomide).

\section{VEGF Receptor Tyrosine Kinase Inhibitor: PTK787, SU5416, and GW654652}

Therapeutic agents targeting VEGF receptor tyrosine kinase include PTK787, SU5416, and GW654652[177,178,179,180]. PTK787, an orally administered tyrosine kinase inhibitor that binds to the ATP-binding sites of VEGF receptors, has been shown in vitro to inhibit MM cell growth and migration as well as inhibit paracrine interactions with IL-6[177]. It is currently undergoing phase I testing in MM. SU5416, a small molecule VEGFR2, was found in phase II clinical trials to have some biologic effects; however, there was minimal clinical response[181]. Finally, the pan-VEGF inhibitor GW654652 acts on both MM cells and the BM microenvironment. GW654652 inhibits the secretion of other prominent cytokines (IL-6) and decreases proliferation even in the presence of BMSC. Phase I clinical trials are planned for the future[180]. 


\section{Targeting the Tumor Necrosis Factor Family}

The tumor necrosis factor family includes numerous ligands, several of which have been studied in MM, including TNF- $\alpha$, tumor necrosis factor-related apoptosis-inducing ligand (TRAIL/Apo2L), Fas, CD40 ligand, B-cell activating factor, BAFF, and APRIL.

\section{TRAIL/Apo2L}

TRAIL/Apo2L appears to have the most potential benefit against myeloma as it has been shown in MM cell lines, MM patient cells, and in xenograft mouse models to induce apoptosis selectively and overcome drug resistance[182,183]. TRAIL binds to two receptors, TRAIL-R1 and TRAIL-R2, which then trimerize and ultimately trigger the activation of caspase cascade and apoptosis.

\section{CD40 Ligand: SGN-40}

CD40 ligand has been shown to effect MM cell proliferation directly via the PI3K/Akt pathway as well as indirectly through induction of IL-6 and VEGF secretion by the BMSCs[184]. Preclinical studies with a humanized anti-CD40 antibody, SGN-40, revealed cytotoxicity even in cell lines resistant to conventional therapies[185]. Furthermore, lenalidomide was shown to augment SGN-40-mediated cytotoxicity[107].

\section{Targeting TGF- $\beta$}

Transforming growth factor (TGF)- $\beta 1$, a multifunctional cytokine that plays a major role in hematopoiesis and tumor progression, is known to enhance IL-6 secretion by BMSCs[142]. It is secreted predominantly by MM cells, and adhesion of MM cells with MM patient BMSCs augments this secretion[186].

\section{TGF- $\beta$ Receptor Tyrosine Kinase Inhibitor: SD-208}

Inhibition of TGF- $\beta 1$ may overcome the growth advantages conferred by MM cell adhesion to BMSCs. SD-208, a selective TGF- $\beta$ receptor type I (T $\beta$ RI) kinase inhibitor, down-regulates both cytokine secretion and proliferation of tumor cells even in the presence of BMSCs[186].

\section{Anti-CD20 Antibody: Rituximab}

CD20 is expressed on the cell surface in roughly $20 \%$ of MM patients, and a CD20+ phenotype is associated with shorter survival[187]. Rituximab, an anti-CD20 monoclonal antibody, is standard therapy for other hematologic malignancies, such as non-Hodgkin's lymphoma. In myeloma, its clinical use is uncertain. It has been studied as a single agent[188,189], with modest results and in combination with melphalan/prednisone, also with equivocal results[190].

\section{NOVEL AGENTS CURRENTLY IN CLINICAL TRIALS}

Many of the novel agents discussed in this review have shown great preclinical promise, both as single agents and in combination with current therapies. There are several upcoming or currently in progress clinical trials for many of these agents (Tables 1-3). Here we will briefly summarize the clinical data for 
several agents that have been more extensively studied: arsenic trioxide, thalidomide, lenalidomide, and bortezomib.

\section{Arsenic Trioxide}

Arsenic trioxide has been evaluated in clinical trials as both a single agent and in combination with other therapies. A phase 2, multicenter, open-label study was conducted in $24 \mathrm{MM}$ patients relapsed or refractory to prior treatments. Patients received arsenic trioxide $(0.25 \mathrm{mg} / \mathrm{kg} / \mathrm{day}$ for 5 day $/$ week $)$ during the first 2 weeks of each 4-week cycle; $58 \%$ had either a $>25 \%$ reduction in serum M-protein levels or had stable disease[191]. Arsenic has also been evaluated in a combination study with dexamethasone and melphalan. In a study of 10 patients with relapsed or refractory disease, arsenic with low-dose melphalan and ascorbic acid exhibited sustained response and treatment was well tolerated[192]. Ascorbic acid potentiates the effects of arsenic by reducing intracellular glutathione, a molecule that functions to repair mitochondrial damage[193]. Currently, phase II trials are underway to evaluate arsenic in combination with bortezomib, thalidomide, and melphalan.

\section{Thalidomide}

Thalidomide has shown excellent results as a single agent in patients with relapsed/refractory myeloma[101,194,195,196] and newly diagnosed disease[197,198,199]. Clinical response (complete, partial, and minor) was achieved in up to $50 \%$ of patients refractory to other treatments, and $30 \%$ of patients with new disease responded with $50 \%$ decreases in paraprotein. Subsequently, it has also been studied in combination with dexamethasone[195,199,200,201,202,203,204,205,206], dexamethasone/ cyclophosphamide[207,208,209,210], melphalan/prednisone[211], and as maintenance therapy following autologous stem cell transplantation[212,213,214].

Thalidomide treatment is associated with several treatment-limiting side effects, including neuropathy ( $50-80 \%$ of patients), venous thromboembolism ( $1-3 \%$ patients with Thal alone; $10-15 \%$ with thal/dex), Stevens-Johnson syndrome, and hepatotoxicity. Other side effects include fatigue, somnolence, constipation, and rash[113]. For this reason, newer, more potent, thalidomide immunomodulatory derivatives were developed with fewer side effects.

\section{Lenalidomide}

Lenalidomide has been found in vitro to be as much as 2000 times more potent than thalidomide. Importantly, clinically it is much better tolerated with only rare neuropathy and reversible myelosuppression. Lenalidomide has also been studied in phase II trials as a single agent and in combination with dexamethasone for relapsed/refractory disease[215,216] as well as newly diagnosed disease[217]. Two large phase III trials of lenalidomide in combination with dexamethasone vs. dexamethasone alone in patients with relapsed/refractory myeloma have been recently presented at the American Society of Hematology annual meeting (2005) by Dimopoulos and colleagues[218]. Two large phase III trials of lenalidomide in combination with dexamethasone versus dexamethasone alone in patients with relapsed/refractory myeloma have been recently presented at the American Society of Hematology annual meeting (2005) by Dimopoulos and colleagues [219] and Clinical Trial number NCT00098475 [220]. These have demonstrated significant activity of the lenalidomide dexamethasone arm with $58 \%$ response rate as compared to $22 \%$ in the dexamethasone arm. Based on these data, lenalidomide was recently approved in 2006 for use in patients who have received prior therapy. In addition, current clinical trials of a combination of lenalidomide with bortezomib in the upfront or relapsed setting are underway. 


\section{Bortezomib}

Bortezomib has seen a remarkable transition from bench to bedside. The SUMMIT trial (Study of Uncontrolled Multiple Myeloma managed with proteasome Inhibition Therapy), a large, multicenter phase II study in 2003, revealed a 35\% response rate[220]. The CREST (Clinical Response and Efficacy Study of bortezomib in the Treatment of myeloma) trial, another phase II study randomizing patients to higher $(1.3 \mathrm{mg} / \mathrm{m} 3)$ or lower $(1.0 \mathrm{mg} / \mathrm{m} 3)$ doses of bortezomib in combination with dexamethasone, revealed positive response rates $(33 \%$ with low-dose bortezomib alone, $44 \%$ with low-dose bortezomib/dex, 50\% with high-dose bortezomib, and 62\% with high-dose bortezomib/dex)[221]. Based on the results from these trials, bortezomib was FDA approved for treatment of relapsed and refractory myeloma in 2003. Subsequently, during interim analysis of an international, randomized, phase III trial of bortezomib vs. high-dose dexamethasone (APEX), bortezomib was found to be clearly superior in terms of overall survival and time to progression, and FDA approval was extended to include relapsed myeloma[222].

Currently, numerous phase I/II trials are underway to examine the effects of bortezomib as first-line therapy and in combination with other agents. Preliminary data from interim analysis in these trials are highly promising for an even greater role of bortezomib in the treatment of myeloma. In relapsed/refractory myeloma, bortezomib is being evaluated in combination with pegylated liposomal doxorubicin[223], melphalan[224], doxorubicin/thalidomide/dexamethasone[225], pegylated liposomal dox/low-dose dex[226], thalidomide and dex[227,228]. As a first-line agent, it is being evaluated in the phase III VISTA trial (Velcade as Initial Standard Therapy in multiple myeloma: Assessment with melphalan and prednisone), with dexamethasone[229], doxorubicin/dexamethasone (PAD)[230], and thalidomide and dexamethasone[231]. Other trials include the bortezomib/lenalidomide trial in newly diagnosed patients with MM.

\section{FUTURE DIRECTIONS: NOVEL DRUG COMBINATIONS}

Treatments for MM have come a long way since therapeutic bleeding and leeches. Though myeloma remains an incurable disease, the recent decade has marked a renaissance in how myeloma is being studied and how new therapies are being developed. There has been a shift towards developing an arsenal of rationally designed, specific agents, each designed at targeting a small aspect of the complex disease. However, despite the advances observed in the treatment of myeloma, many patients still succumb to their disease. In addition, many agents that were exciting and promising in preclinical trials, fail to demonstrate similarly promising clinical activity as single agents in clinical trials. As such, one of the major challenges on the road towards improved survival and, perhaps, a cure, lies in the identification of not just promising agents, but combinations of agents. There is an urgent need for future clinical trials designed to combine novel agents rationally in order to achieve a higher response rate and longer remissions.

To date, there are already a vast number of in vitro and in vivo studies that hint at the myriad of pathways that can be targeted for a synergistic, multihit approach. Identifying these areas of molecular synergism depends on close collaboration between basic researchers at the bench and clinicians at the bedside, and will surely help to overcome drug resistance, extend patient survival, and improve quality of life.

\section{ACKNOWLEDGMENTS}

KCA is supported in part by NIH grants RO-1 50947 and PO1-78378, Doris Duke Distinguished Clinical Research Scientist Award, and the Cure for Myeloma Fund. JJH is a Howard Hughes Medical Institute Medical Research Training Fellow. IMG is a Lymphoma Research Scholar and supported in part by the Leukemia and Lymphoma Society, an ASH Scholar award, and the Multiple Myeloma Research Foundation. 


\section{REFERENCES}

1. $\quad$ Solly, S. (1844) Med. Chir. Trans. Lond. 27, 1844.

2. Kyle, R.A. (2000) Multiple myeloma: an odyssey of discovery. Br. J. Haematol. 111(4), 1035-1044.

3. Blokhin, N.E.A. (1958) Ann. N. Y. Acad. Sci. 68, 1128.

4. (1998) Combination chemotherapy versus melphalan plus prednisone as treatment for multiple myeloma: an overview of 6,633 patients from 27 randomized trials. Myeloma Trialists' Collaborative Group. J. Clin. Oncol. 16(12), 38323842 .

5. Preud'homme, J.L., Klein, M., Labaume, S., and Seligmann, M. (1977) Idiotype-bearing and antigen-binding receptors produced by blood T lymphocytes in a case of human myeloma. Eur. J. Immunol. 7(12), 840-846.

6. $\quad$ Chesi, M., Bergsagel, P.L., Brents, L.A., Smith, C.M., Gerhard, D.S., and Kuehl, W.M. (1996) Dysregulation of cyclin D1 by translocation into an IgH gamma switch region in two multiple myeloma cell lines. Blood 88(2), 674681.

7. Chesi, M., Bergsagel, P.L., and Kuehl, W.M. (2002) The enigma of ectopic expression of FGFR3 in multiple myeloma: a critical initiating event or just a target for mutational activation during tumor progression. Curr. Opin. Hematol. 9(4), 288-293.

8. Chesi, M., Bergsagel, P.L., Shonukan, O.O., Martelli, M.L., Brents, L.A., Chen, T., Schrock, E., Ried, T., and Kuehl, W.M. (1998) Frequent dysregulation of the c-maf proto-oncogene at $16 \mathrm{q} 23$ by translocation to an Ig locus in multiple myeloma. Blood 91(12), 4457-4463.

9. Chesi, M., Nardini, E., Brents, L.A., Schrock, E., Ried, T., Kuehl, W.M., and Bergsagel, P.L. (1997) Frequent translocation $\mathrm{t}(4 ; 14)(\mathrm{p} 16.3 ; \mathrm{q} 32.3)$ in multiple myeloma is associated with increased expression and activating mutations of fibroblast growth factor receptor 3. Nat Genet. 16(3), 260-264.

10. Chesi, M., Nardini, E., Lim, R.S., Smith, K.D., Kuehl, W.M., and Bergsagel, P.L. (1998) The t(4;14) translocation in myeloma dysregulates both FGFR3 and a novel gene, MMSET, resulting in IgH/MMSET hybrid transcripts. Blood 92(9), 3025-3034.

11. Bergsagel, P.L., Kuehl, W.M., Zhan, F., Sawyer, J., Barlogie, B., and Shaughnessy, J., Jr. (2005) Cyclin D dysregulation: an early and unifying pathogenic event in multiple myeloma. Blood 106(1), 296-303.

12. Hideshima, T. and Anderson, K.C. (2002) Molecular mechanisms of novel therapeutic approaches for multiple myeloma. Nat. Rev. Cancer 2(12), 927-937.

13. Mitsiades, C.S., Mitsiades, N., Munshi, N.C., and Anderson, K.C. (2004) Focus on multiple myeloma. Cancer Cell 6(5), 439-444.

14. Kuehl, W.M. and Bergsagel, P.L. (2002) Multiple myeloma: evolving genetic events and host interactions. Nat. Rev. Cancer 2(3), 175-187.

15. Burgering, B.M. and Medema, R.H. (2003) Decisions on life and death: FOXO Forkhead transcription factors are in command when PKB/Akt is off duty. J. Leukoc. Biol. 73(6), 689-701.

16. Datta, S.R., Brunet, A., and Greenberg, M.E. (1999) Cellular survival: a play in three Akts. Genes Dev. 13(22), 29052927.

17. Ozes, O.N., Mayo, L.D., Gustin, J.A., Pfeffer, S.R., Pfeffer, L.M., and Donner, D.B. (1999) NF-kappaB activation by tumour necrosis factor requires the Akt serine-threonine kinase. Nature 401(6748), 82-85.

18. Trotman, L.C., Niki, M., Dotan, Z.A., Koutcher, J.A., Di Cristofano, A., Xiao, A., Khoo, A.S., Roy-Burman, P., Greenberg, N.M., Van Dyke, T., Cordon-Cardo, C., and Pandolfi, P.P. (2003) Pten dose dictates cancer progression in the prostate. PLoS Biol. 1(3), E59.

19. Diehl, J.A., Cheng, M., Roussel, M.F., and Sherr, C.J. (1998) Glycogen synthase kinase-3beta regulates cyclin D1 proteolysis and subcellular localization. Genes Dev. 12(22), 3499-3511.

20. Brunn, G.J., Williams, J., Sabers, C., Wiederrecht, G., Lawrence, J.C., Jr., and Abraham, R.T. (1996) Direct inhibition of the signaling functions of the mammalian target of rapamycin by the phosphoinositide 3-kinase inhibitors, wortmannin and LY294002. EMBO J. 15(19), 5256-5267.

21. Nave, B.T., Ouwens, M., Withers, D.J., Alessi, D.R., and Shepherd, P.R. (1999) Mammalian target of rapamycin is a direct target for protein kinase B: identification of a convergence point for opposing effects of insulin and amino-acid deficiency on protein translation. Biochem J. 344(Pt 2), 427-431.

22. Yan, H., Frost, P., Shi, Y., Hoang, B., Sharma, S., Fisher, M., Gera, J., and Lichtenstein, A. (2006) Mechanism by which mammalian target of rapamycin inhibitors sensitize multiple myeloma cells to dexamethasone-induced apoptosis. Cancer Res. 66(4), 2305-2313.

23. Tu, Y., Gardner, A., and Lichtenstein, A. (2000) The phosphatidylinositol 3-kinase/AKT kinase pathway in multiple myeloma plasma cells: roles in cytokine-dependent survival and proliferative responses. Cancer Res. 60(23), 67636770 .

24. Hideshima, T., Nakamura, N., Chauhan, D., and Anderson, K.C. (2001) Biologic sequelae of interleukin-6 induced PI3-K/Akt signaling in multiple myeloma. Oncogene 20(42), 5991-6000.

25. Vivanco, I. and Sawyers, C.L. (2002) The phosphatidylinositol 3-kinase AKT pathway in human cancer. Nat. Rev. Cancer 2(7), 489-501.

26. Vink, S.R., Schellens, J.H., van Blitterswijk, W.J., and Verheij, M. (2005) Tumor and normal tissue pharmacokinetics of perifosine, an oral anti-cancer alkylphospholipid. Invest. New Drugs 23(4), 279-286. 
27. Kondapaka, S.B., Singh, S.S., Dasmahapatra, G.P., Sausville, E.A., and Roy, K.K. (2003) Perifosine, a novel alkylphospholipid, inhibits protein kinase B activation. Mol. Cancer Ther. 2(11), 1093-1103.

28. Patel, V., Lahusen, T., Sy, T., Sausville, E.A., Gutkind, J.S., and Senderowicz, A.M. (2002) Perifosine, a novel alkylphospholipid, induces p21(WAF1) expression in squamous carcinoma cells through a p53-independent pathway, leading to loss in cyclin-dependent kinase activity and cell cycle arrest. Cancer Res. 62(5), 1401-1409.

29. Crul, M., Rosing, H., de Klerk, G.J., Dubbelman, R., Traiser, M., Reichert, S., Knebel, N.G., Schellens, J.H., Beijnen, J.H., and ten Bokkel Huinink, W.W. (2002) Phase I and pharmacological study of daily oral administration of perifosine (D-21266) in patients with advanced solid tumours. Eur. J. Cancer 38(12), 1615-1621.

30. Hideshima, T., Catley, L., Yasui, H., Ishitsuka, K., Raje, N., Mitsiades, C., Podar, K., Munshi, N.C., Chauhan, D., Richardson, P.G., and Anderson, K.C. (2006) Perifosine, an oral bioactive novel alkylphospholipid, inhibits Akt and induces in vitro and in vivo cytotoxicity in human multiple myeloma cells. Blood 107(10), 4053-4062.

31. Sabers, C.J., Martin, M.M., Brunn, G.J., Williams, J.M., Dumont, F.J., Wiederrecht, G., and Abraham, R.T. (1995) Isolation of a protein target of the FKBP12-rapamycin complex in mammalian cells. J. Biol. Chem. 270(2), 815-822. Stromberg, T., Dimberg, A., Hammarberg, A., et al. (2004) Rapamycin sensitizes multiple myeloma cells to apoptosis induced by dexamethasone. Blood 103(8), 3138-3147.

33. Janus, A., Robak, T., and Smolewski, P. (2005) The mammalian target of the rapamycin (mTOR) kinase pathway: its role in tumourigenesis and targeted antitumour therapy. Cell. Mol. Biol. Lett. 10(3), 479-498.

34. Podar, K., Raab, M.S., Abtahi, D., Tai, Y.-T., Lin, B., Munshi, N.C., Hideshima, T., Chauhan, D., and Anderson, K.C. (2005) The PKC-Inhibitor Enzastaurin Inhibits MM Cell Growth, Survival and Migration in the Bone Marrow Microenvironment. ASH Annual Meeting Abstracts. Blood 106(11), 1584.

35. Rizvi, M.A., Ghias, K., Davies, K.M., Ma, C., Krett, N.L., and Rosen, S.T. (2005) Enzastaurin (LY317615), an Oral Protein Kinase C \{beta\} Inhibitor, Induces Apoptosis in Multiple Myeloma Cell Lines. ASH Annual Meeting Abstracts. Blood 106(11), 1577.

36. Platanias, L.C. (2003) Map kinase signaling pathways and hematologic malignancies. Blood 101(12), 4667-4679.

37. Hideshima, T., Akiyama, M., Hayashi, T., Richardson, P., Schlossman, R., Chauhan, D., and Anderson, K.C. (2003) Targeting p38 MAPK inhibits multiple myeloma cell growth in the bone marrow milieu. Blood 101(2), 703-705.

38. Hideshima, T., Podar, K., Chauhan, D., and Anderson, K.C. (2005) Cytokines and signal transduction. Best Pract. Res. Clin. Haematol. 18(4), 509-524.

39. Chauhan, D., Kharbanda, S., Ogata, A., Urashima, M., Teoh, G., Robertson, M., Kufe, D.W., and Anderson, K.C. (1997) Interleukin-6 inhibits Fas-induced apoptosis and stress-activated protein kinase activation in multiple myeloma cells. Blood 89(1), 227-234.

40. Hu, L., Shi, Y., Hsu, J.H., Gera, J., Van Ness, B., and Lichtenstein, A. (2003) Downstream effectors of oncogenic ras in multiple myeloma cells. Blood 101(8), 3126-3135.

41. Corradini, P., Ladetto, M., Inghirami, G., Boccadoro, M., and Pileri, A. (1994) N- and K-ras oncogenes in plasma cell dyscrasias. Leuk. Lymphoma 15(1-2), 17-20.

42. Corradini, P., Ladetto, M., Voena, C., Palumbo, A., Inghirami, G., Knowles, D.M., Boccadoro, M., and Pileri, A. (1993) Mutational activation of N- and K-ras oncogenes in plasma cell dyscrasias. Blood 81(10), 2708-2713.

43. Ogata, A., Chauhan, D., Teoh, G., Treon, S.P., Urashima, M., Schlossman, R.L., and Anderson, K.C. (1997) IL-6 triggers cell growth via the Ras-dependent mitogen-activated protein kinase cascade. J. Immunol. 159(5), $2212-2221$. Ogata, A., Chauhan, D., Urashima, M., Teoh, G., Treon, S.P., and Anderson, K.C. (1997) Blockade of mitogenactivated protein kinase cascade signaling in interleukin 6-independent multiple myeloma cells. Clin. Cancer Res. 3(6), 1017-1022.

45. Zhang, B. and Fenton, R.G. (2002) Proliferation of IL-6-independent multiple myeloma does not require the activity of extracellular signal-regulated kinases (ERK1/2). J. Cell Physiol. 193(1), 42-54.

46. Pei, X.Y., Dai, Y., Rahmani, M., Li, W., Dent, P., and Grant, S. (2005) The farnesyltransferase inhibitor L744832 potentiates UCN-01-induced apoptosis in human multiple myeloma cells. Clin. Cancer Res. 11(12), 4589-4600. Frassanito, M.A., Mastromauro, L., Cusmai, A., and Dammacco, F. (2005) Blockade of the Ras pathway by manumycin, a farnesyltransferase inhibitor, overcomes the resistance of myeloma plasma cells to Fas-induced apoptosis. Clin. Exp. Med. 4(4), 174-182.

48. Gomez-Benito, M., Marzo, I., Anel, A., and Naval, J. (2005) Farnesyltransferase inhibitor BMS-214662 induces apoptosis in myeloma cells through PUMA up-regulation, Bax and Bak activation, and Mcl-1 elimination. Mol. Pharmacol. 67(6), 1991-1998.

49. David, E., Sun, S.Y., Waller, E.K., Chen, J., Khuri, F.R., and Lonial, S. (2005) The combination of the farnesyl transferase inhibitor lonafarnib and the proteasome inhibitor bortezomib induces synergistic apoptosis in human myeloma cells that is associated with down-regulation of p-AKT. Blood 106(13), 4322-4329.

50. Alsina, M., Fonseca, R., Wilson, E.F., Belle, A.N., Gerbino, E., Price-Troska, T., Overton, R.M., Ahmann, G., Bruzek, L.M., Adjei, A.A., Kaufmann, S.H., Wright, J.J., Sullivan, D., Djulbegovic, B., Cantor, A.B., Greipp, P.R., Dalton, W.S., and Sebti, S.M. (2004) Farnesyltransferase inhibitor tipifarnib is well tolerated, induces stabilization of disease, and inhibits farnesylation and oncogenic/tumor survival pathways in patients with advanced multiple myeloma. Blood 103(9), 3271-3277.

51. Bayes, M., Rabasseda, X., and Prous, J.R. (2004) Gateways to clinical trials. Methods Find. Exp. Clin. Pharmacol. 26(5), 357-391. 
52. Zhu, K., Gerbino, E., Beaupre, D.M., Mackley, P.A., Muro-Cacho, C., Beam, C., Hamilton, A.D., Lichtenheld, M.G., Kerr, W.G., Dalton, W., Alsina, M., and Sebti, S.M. (2005) Farnesyltransferase inhibitor R115777 (Zarnestra, Tipifarnib) synergizes with paclitaxel to induce apoptosis and mitotic arrest and to inhibit tumor growth of multiple myeloma cells. Blood 105(12), 4759-4766.

53. Olson, J.M. and Hallahan, A.R. (2004) p38 MAP kinase: a convergence point in cancer therapy. Trends Mol. Med. 10(3), 125-129.

54. Hideshima, T., Podar, K., Chauhan, D., Ishitsuka, K., Mitsiades, C., Tai, Y.T., Hamasaki, M., Raje, N., Hideshima, H., Schreiner, G., Nguyen, A.N., Navas, T., Munshi, N.C., Richardson, P.G., Higgins, L.S., and Anderson, K.C. (2004) p38 MAPK inhibition enhances PS-341 (bortezomib)-induced cytotoxicity against multiple myeloma cells. Oncogene 23(54), 8766-8776.

55. Navas, T.A., Nguyen, A.N., Hideshima, T., Reddy, M., Ma, J.Y., Haghnazari, E., Henson, M., Stebbins, E.G., Kerr, I., O'Young, G., Kapoun, A.M., Chakravarty, S., Mavunkel, B., Perumattam, J., Luedtke, G., Dugar, S., Medicherla, S., Protter, A.A., Schreiner, G.F., Anderson, K.C., and Higgins, L.S. (2006) Inhibition of p38alpha MAPK enhances proteasome inhibitor-induced apoptosis of myeloma cells by modulating Hsp27, Bcl-X(L), Mcl-1 and p53 levels in vitro and inhibits tumor growth in vivo. Leukemia 20(6), 1017-1027.

56. Hibi, M., Lin, A., Smeal, T., Minden, A., and Karin, M. (1993) Identification of an oncoprotein- and UV-responsive protein kinase that binds and potentiates the c-Jun activation domain. Genes Dev. 7(11), 2135-2148.

57. Bossy-Wetzel, E., Bakiri, L., and Yaniv, M. (1997) Induction of apoptosis by the transcription factor c-Jun. EMBO J. 16(7), 1695-1709.

58. Xu, F.H., Sharma, S., Gardner, A., Tu, Y., Raitano, A., Sawyers, C., and Lichtenstein, A. (1998) Interleukin-6induced inhibition of multiple myeloma cell apoptosis: support for the hypothesis that protection is mediated via inhibition of the JNK/SAPK pathway. Blood 92(1), 241-251.

59. Hideshima, T., Hayashi, T., Chauhan, D., Akiyama, M., Richardson, P., and Anderson, K. (2003) Biologic sequelae of c-Jun NH(2)-terminal kinase (JNK) activation in multiple myeloma cell lines. Oncogene 22(54), 8797-8801.

60. Hideshima, T., Richardson, P.G., and Anderson, K.C. (2003) Targeting proteasome inhibition in hematologic malignancies. Rev. Clin. Exp. Hematol. 7(2), 191-204.

61. Cuadrado, A., Garcia-Fernandez, L.F., Gonzalez, L., Suarez, Y., Losada, A., Alcaide, V., Martinez, T., FernandezSousa, J.M., Sanchez-Puelles, J.M., and Munoz, A. (2003) Aplidin induces apoptosis in human cancer cells via glutathione depletion and sustained activation of the epidermal growth factor receptor, Src, JNK, and p38 MAPK. J. Biol. Chem. 278(1), 241-250.

62. Cuadrado, A., Gonzalez, L., Suarez, Y., Martinez, T., and Munoz, A. (2004) JNK activation is critical for Aplidininduced apoptosis. Oncogene 23(27), 4673-4680.

63. Gonzalez-Santiago, L., Suarez, Y., Zarich, N., Munoz-Alonso, M.J., Cuadrado, A., Martinez, T., Goya, L., Iradi, A., Saez-Tormo, G., Maier, J.V., Moorthy, A., Cato, A.C., Rojas, J.M., and Munoz, A. (2006) Aplidin((R)) induces JNKdependent apoptosis in human breast cancer cells via alteration of glutathione homeostasis, Rac1 GTPase activation, and MKP-1 phosphatase downregulation. Cell Death Differ., in press.

64. Bruno, B., Giaccone, L., Rotta, M., Anderson, K., and Boccadoro, M. (2005) Novel targeted drugs for the treatment of multiple myeloma: from bench to bedside. Leukemia 19(10), 1729-1738.

65. Lopez-Martin, J., M. Izquierdo, J. Jimeno, G. Faircloth. Aplidin ${ }^{\circledR}$ (Aplidium albicans): Non-Clinical and Clinical Bases For a Clinical Evaluation in Patients With Multiple Myeloma. in Multiple Myeloma Research Foundation Round Table. 2004. Torino, Italy.

66. Bours, V., Bentires-Alj, M., Hellin, A.C., Viatour, P., Robe, P., Delhalle, S., Benoit, V., and Merville, M.P. (2000) Nuclear factor-kappa B, cancer, and apoptosis. Biochem. Pharmacol. 60(8), 1085-1089.

67. Viatour, P., Legrand-Poels, S., van Lint, C., Warnier, M., Merville, M.P., Gielen, J., Piette, J., Bours, V., and Chariot, A. (2003) Cytoplasmic IkappaBalpha increases NF-kappaB-independent transcription through binding to histone deacetylase (HDAC) 1 and HDAC3. J. Biol. Chem. 278(47), 46541-46548.

68. Viatour, P., Merville, M.P., Bours, V., and Chariot, A. (2005) Phosphorylation of NF-kappaB and IkappaB proteins: implications in cancer and inflammation. Trends Biochem. Sci. 30(1), 43-52.

69. Feinman, R., Siegel, D.S., and Berenson, J. (2004) Regulation of NF-kB in multiple myeloma: therapeutic implications. Clin. Adv. Hematol. Oncol. 2(3), 162-166.

70. Ni, H., Ergin, M., Huang, Q., Qin, J.Z., Amin, H.M., Martinez, R.L., Saeed, S., Barton, K., and Alkan, S. (2001) Analysis of expression of nuclear factor kappa B (NF-kappa B) in multiple myeloma: downregulation of NF-kappa B induces apoptosis. Br. J. Haematol. 115(2), 279-286.

71. Hideshima, T., Chauhan, D., Richardson, P., Mitsiades, C., Mitsiades, N., Hayashi, T., Munshi, N., Dang, L., Castro, A., Palombella, V., Adams, J., and Anderson, K.C. (2002) NF-kappa B as a therapeutic target in multiple myeloma. J. Biol. Chem. 277(19), 16639-16647.

72. Hideshima, T., Mitsiades, C., Akiyama, M., Hayashi, T., Chauhan, D., Richardson, P., Schlossman, R., Podar, K., Munshi, N.C., Mitsiades, N., and Anderson, K.C. (2003) Molecular mechanisms mediating antimyeloma activity of proteasome inhibitor PS-341. Blood 101(4), 1530-1534.

73. Mitsiades, N., Mitsiades, C.S., Poulaki, V., Chauhan, D., Richardson, P.G., Hideshima, T., Munshi, N., Treon, S.P., and Anderson, K.C. (2002) Biologic sequelae of nuclear factor-kappaB blockade in multiple myeloma: therapeutic applications. Blood 99(11), 4079-4086. 
74. Feinman, R., Koury, J., Thames, M., Barlogie, B., Epstein, J., and Siegel, D.S. (1999) Role of NF-kappaB in the rescue of multiple myeloma cells from glucocorticoid-induced apoptosis by bcl-2. Blood 93(9), 3044-3052.

75. Mitsiades, N., Mitsiades, C.S., Poulaki, V., Chauhan, D., Richardson, P.G., Hideshima, T., Munshi, N.C., Treon, S.P., and Anderson, K.C. (2002) Apoptotic signaling induced by immunomodulatory thalidomide analogs in human multiple myeloma cells: therapeutic implications. Blood 99(12), 4525-4530.

76. Hideshima, T., Richardson, P., Chauhan, D., Palombella, V.J., Elliott, P.J., Adams, J., and Anderson, K.C. (2001) The proteasome inhibitor PS-341 inhibits growth, induces apoptosis, and overcomes drug resistance in human multiple myeloma cells. Cancer Res. 61(7), 3071-3076.

77. Jourdan, M., De Vos, J., Mechti, N., and Klein, B. (2000) Regulation of Bcl-2-family proteins in myeloma cells by three myeloma survival factors: interleukin-6, interferon-alpha and insulin-like growth factor 1. Cell Death Differ. 7(12), 1244-1252.

78. Brocke-Heidrich, K., Kretzschmar, A.K., Pfeifer, G., Henze, C., Loffler, D., Koczan, D., Thiesen, H.J., Burger, R., Gramatzki, M., and Horn, F. (2004) Interleukin-6-dependent gene expression profiles in multiple myeloma INA-6 cells reveal a Bcl-2 family-independent survival pathway closely associated with Stat3 activation. Blood 103(1), 242251.

79. Derenne, S., Monia, B., Dean, N.M., Taylor, J.K., Rapp, M.J., Harousseau, J.L., Bataille, R., and Amiot, M. (2002) Antisense strategy shows that Mcl-1 rather than Bcl-2 or Bcl-x(L) is an essential survival protein of human myeloma cells. Blood 100(1), 194-199.

80. Alas, S. and Bonavida, B. (2003) Inhibition of constitutive STAT3 activity sensitizes resistant non-Hodgkin's lymphoma and multiple myeloma to chemotherapeutic drug-mediated apoptosis. Clin. Cancer Res. 9(1), 316-326.

81. Schmidbauer, G., Hancock, W.W., Badger, A.M., and Kupiec-Weglinski, J.W. (1993) Induction of nonspecific xirradiation-resistant suppressor cell activity in vivo and prolongation of vascularized allograft survival by SK\&F 105685, a novel immunomodulatory azaspirane. Transplantation 55(6), 1236-1243.

82. Amit-Vazina, M., Shishodia, S., Harris, D., Van, Q., Wang, M., Weber, D., Alexanian, R., Talpaz, M., Aggarwal, B.B., and Estrov, Z. (2005) Atiprimod blocks STAT3 phosphorylation and induces apoptosis in multiple myeloma cells. Br. J. Cancer 93(1), 70-80.

83. Hamasaki, M., Hideshima, T., Tassone, P., Neri, P., Ishitsuka, K., Yasui, H., Shiraishi, N., Raje, N., Kumar, S., Picker, D.H., Jacob, G.S., Richardson, P.G., Munshi, N.C., and Anderson, K.C. (2005) In vitro and in vivo activity of atiprimod (N-N-diethl-8,8-dipropyl-2-azaspiro [4.5] decane-2-propanamine) inhibits human multiple myeloma cell growth in the bone marrow milieu. Blood. 105(11), 4470-4476.

84. Shao, W., Fanelli, M., Ferrara, F.F., Riccioni, R., Rosenauer, A., Davison, K., Lamph, W.W., Waxman, S., Pelicci, P.G., Lo Coco, F., Avvisati, G., Testa, U., Peschle, C., Gambacorti-Passerini, C., Nervi, C., and Miller, W.H., Jr. (1998) Arsenic trioxide as an inducer of apoptosis and loss of PML/RAR alpha protein in acute promyelocytic leukemia cells. J. Natl. Cancer Inst. 90(2), 124-133.

85. Rousselot, P., Labaume, S., Marolleau, J.P., Larghero, J., Noguera, M.H., Brouet, J.C., and Fermand, J.P. (1999) Arsenic trioxide and melarsoprol induce apoptosis in plasma cell lines and in plasma cells from myeloma patients. Cancer Res. 59(5), 1041-1048.

86. Hayashi, T., Hideshima, T., Akiyama, M., Richardson, P., Schlossman, R.L., Chauhan, D., Munshi, N.C., Waxman, S., and Anderson, K.C. (2002) Arsenic trioxide inhibits growth of human multiple myeloma cells in the bone marrow microenvironment. Mol. Cancer Ther. 1(10), 851-860.

87. Liu, Q., Hilsenbeck, S., and Gazitt, Y. (2003) Arsenic trioxide-induced apoptosis in myeloma cells: p53-dependent G1 or G2/M cell cycle arrest, activation of caspase- 8 or caspase-9, and synergy with APO2/TRAIL. Blood 101(10), 4078-4087.

88. Hideshima, T., Chauhan, D., Hayashi, T., Podar, K., Akiyama, M., Mitsiades, C., Mitsiades, N., Gong, B., Bonham, L., de Vries, P., Munshi, N., Richardson, P.G., Singer, J.W., and Anderson, K.C. (2003) Antitumor activity of lysophosphatidic acid acyltransferase-beta inhibitors, a novel class of agents, in multiple myeloma. Cancer Res. 63(23), 8428-8436.

89. Hideshima, T., Chauhan, D., Ishitsuka, K., Yasui, H., Raje, N., Kumar, S., Podar, K., Mitsiades, C., Hideshima, H., Bonham, L., Munshi, N.C., Richardson, P.G., Singer, J.W., and Anderson, K.C. (2005) Molecular characterization of PS-341 (bortezomib) resistance: implications for overcoming resistance using lysophosphatidic acid acyltransferase (LPAAT)-beta inhibitors. Oncogene 24(19), 3121-3129.

90. Chauhan, D., Catley, L., Hideshima, T., Li, G., Leblanc, R., Gupta, D., Sattler, M., Richardson, P., Schlossman, R.L., Podar, K., Weller, E., Munshi, N., and Anderson, K.C. (2002) 2-Methoxyestradiol overcomes drug resistance in multiple myeloma cells. Blood 100(6), 2187-2194.

91. Banerjeei, S.K., Zoubine, M.N., Sarkar, D.K., Weston, A.P., Shah, J.H., and Campbell, D.R. (2000) 2Methoxyestradiol blocks estrogen-induced rat pituitary tumor growth and tumor angiogenesis: possible role of vascular endothelial growth factor. Anticancer Res. 20(4), 2641-2645.

92. Chauhan, D. and Anderson, K.C. (2003) Mechanisms of cell death and survival in multiple myeloma (MM): therapeutic implications. Apoptosis 8(4), 337-343.

93. Chauhan, D., Velankar, M., Hideshima, T., Mitsiades, C., Catley, L., Raje, N., Schlossman, R., Richardson, P., and Anderson, K.C. (2005) Targeting Bcl-2 as Therapy for Multiple Myeloma. ASH Annual Meeting Abstracts. Blood 106(11), 109. 
94. Oltersdorf, T., Elmore, S.W., Shoemaker, A.R., Armstrong, R.C., Augeri, D.J., Belli, B.A., Bruncko, M., Deckwerth, T.L., Dinges, J., Hajduk, P.J., Joseph, M.K., Kitada, S., Korsmeyer, S.J., Kunzer, A.R., Letai, A., Li, C., Mitten, M.J., Nettesheim, D.G., Ng, S., Nimmer, P.M., O'Connor, J.M., Oleksijew, A., Petros, A.M., Reed, J.C., Shen, W., Tahir, S.K., Thompson, C.B., Tomaselli, K.J., Wang, B., Wendt, M.D., Zhang, H., Fesik, S.W., and Rosenberg, S.H. (2005) An inhibitor of Bcl-2 family proteins induces regression of solid tumours. Nature 435(7042), 677-681.

95. Kline, M., Kimlinger, T., Timm, M., Haug, J., Lust, J.A., Rajkumar, S.V., and Kumar, S. (2005) ABT-737, an Inhibitor of Bcl-2/Bcl-XL Proteins, Is Cytotoxic in Multiple Myeloma Cells. ASH Annual Meeting Abstracts. Blood 106(11), 1589.

96. Ikeda, T., Nakata, Y., Kimura, F., Sato, K., Anderson, K., Motoyoshi, K., Sporn, M., and Kufe, D. (2004) Induction of redox imbalance and apoptosis in multiple myeloma cells by the novel triterpenoid 2-cyano-3,12-dioxoolean-1,9dien-28-oic acid. Mol. Cancer Ther. 3(1), 39-45.

97. Ishitsuka, K., Hideshima, T., Hamasaki, M., Raje, N., Kumar, S., Podar, K., Le Gouill, S., Shiraishi, N., Yasui, H., Roccaro, A.M., Tai, Y.Z., Chauhan, D., Fram, R., Tamura, K., Jain, J., and Anderson, K.C. (2005) Novel inosine monophosphate dehydrogenase inhibitor VX-944 induces apoptosis in multiple myeloma cells primarily via caspaseindependent AIF/Endo G pathway. Oncogene 24(38), 5888-5896.

98. Yasui, H., Hideshima, T., Raje, N., Roccaro, A.M., Shiraishi, N., Kumar, S., Hamasaki, M., Ishitsuka, K., Tai, Y.T., Podar, K., Catley, L., Mitsiades, C.S., Richardson, P.G., Albert, R., Brinkmann, V., Chauhan, D., and Anderson, K.C. (2005) FTY720 induces apoptosis in multiple myeloma cells and overcomes drug resistance. Cancer Res. 65(16), $7478-7484$.

99. Yasui, H., Hideshima, T., Hamasaki, M., Roccaro, A.M., Shiraishi, N., Kumar, S., Tassone, P., Ishitsuka, K., Raje, N., Tai, Y.T., Podar, K., Chauhan, D., Leoni, L.M., Kanekal, S., Elliott, G., Munshi, N.C., and Anderson, K.C. (2005) SDX-101, the R-enantiomer of etodolac, induces cytotoxicity, overcomes drug resistance, and enhances the activity of dexamethasone in multiple myeloma. Blood 106(2), 706-712.

100. Singhal, S., Mehta, J., Desikan, R., Ayers, D., Roberson, P., Eddlemon, P., Munshi, N., Anaissie, E., Wilson, C., Dhodapkar, M., Zeddis, J., and Barlogie, B. (1999) Antitumor activity of thalidomide in refractory multiple myeloma. N. Engl. J. Med. 341(21), 1565-1571.

101. Barlogie, B., Desikan, R., Eddlemon, P., Spencer, T., Zeldis, J., Munshi, N., Badros, A., Zangari, M., Anaissie, E., Epstein, J., Shaughnessy, J., Ayers, D., Spoon, D., and Tricot, G. (2001) Extended survival in advanced and refractory multiple myeloma after single-agent thalidomide: identification of prognostic factors in a phase 2 study of 169 patients. Blood 98(2), 492-494.

102. Gupta, D., Hideshima, T., and Anderson, K.C. (2002) Novel biologically based therapeutic strategies in myeloma. Rev. Clin. Exp. Hematol. 6(3), 301-324.

103. Hayashi, T., Hideshima, T., and Anderson, K.C. (2003) Novel therapies for multiple myeloma. Br. J. Haematol. 120(1), 10-17.

104. Hideshima, T., Chauhan, D., Podar, K., Schlossman, R.L., Richardson, P., and Anderson, K.C. (2001) Novel therapies targeting the myeloma cell and its bone marrow microenvironment. Semin. Oncol. 28(6), 607-612.

105. Munshi, N.C., Hideshima, T., Chauhan, D., Richardson, P., and Anderson, K.C. (2002) Novel biologically based therapies for multiple myeloma. Int. J. Hematol. 76(Suppl 1), 340-341.

106. Pagnucco, G., Cardinale, G., and Gervasi, F. (2004) Targeting multiple myeloma cells and their bone marrow microenvironment. Ann. N. Y. Acad. Sci. 1028, 390-399.

107. Tai, Y.T., Li, X.F., Catley, L., Coffey, R., Breitkreutz, I., Bae, J., Song, W., Podar, K., Hideshima, T., Chauhan, D., Schlossman, R., Richardson, P., Treon, S.P., Grewal, I.S., Munshi, N.C., and Anderson, K.C. (2005) Immunomodulatory drug lenalidomide (CC-5013, IMiD3) augments anti-CD40 SGN-40-induced cytotoxicity in human multiple myeloma: clinical implications. Cancer Res. 65(24), 11712-11720.

108. Tohnya, T.M., Ng, S.S., Dahut, W.L., Wright, J.J., Arlen, P.M., Gulley, J.L., Parker, C., Zeldis, J., and Figg, W.D. (2004) A phase I study of oral CC-5013 (lenalidomide, Revlimid), a thalidomide derivative, in patients with refractory metastatic cancer. Clin. Prostate Cancer 2(4), 241-243.

109. Anderson, G., Gries, M., Kurihara, N., Honjo, T., Anderson, J., Donnenberg, V., Donnenberg, A., Ghobrial, I., Mapara, M.Y., Stirling, D., Roodman, D., and Lentzsch, S. (2006) Thalidomide derivative CC-4047 inhibits osteoclast formation by down-regulation of PU.1. Blood 107(8), 3098-3105.

110. Schey, S.A., Fields, P., Bartlett, J.B., Clarke, I.A., Ashan, G., Knight, R.D., Streetly, M., and Dalgleish, A.G. (2004) Phase I study of an immunomodulatory thalidomide analog, CC-4047, in relapsed or refractory multiple myeloma. $J$. Clin. Oncol. 22(16), 3269-3276.

111. Anderson, K.C. (2005) Lenalidomide and thalidomide: mechanisms of action-similarities and differences. Semin. Hematol. 42(4 Suppl 4), S3-8.

112. Hideshima, T., Richardson, P.G., and Anderson, K.C. (2006) Current therapeutic uses of lenalidomide in multiple myeloma. Expert Opin. Investig. Drugs 15(2), 171-179.

113. Morgan, G.J., Krishnan, B., Jenner, M., and Davies, F.E. (2006) Advances in oral therapy for multiple myeloma. Lancet Oncol. 7(4), 316-325.

114. Altun, M., Galardy, P.J., Shringarpure, R., Hideshima, T., LeBlanc, R., Anderson, K.C., Ploegh, H.L., and Kessler, B.M. (2005) Effects of PS-341 on the activity and composition of proteasomes in multiple myeloma cells. Cancer Res. 65(17), 7896-7901. 
115. Chauhan, D., Hideshima, T., Mitsiades, C., Richardson, P., and Anderson, K.C. (2005) Proteasome inhibitor therapy in multiple myeloma. Mol. Cancer Ther. 4(4), 686-692.

116. Hideshima, T., Chauhan, D., Hayashi, T., Akiyama, M., Mitsiades, N., Mitsiades, C., Podar, K., Munshi, N.C., Richardson, P.G., and Anderson, K.C. (2003) Proteasome inhibitor PS-341 abrogates IL-6 triggered signaling cascades via caspase-dependent downregulation of gp130 in multiple myeloma. Oncogene 22(52), 8386-8393.

117. Mitsiades, N., Mitsiades, C.S., Poulaki, V., Chauhan, D., Fanourakis, G., Gu, X., Bailey, C., Joseph, M., Libermann, T.A., Treon, S.P., Munshi, N.C., Richardson, P.G., Hideshima, T., and Anderson, K.C. (2002) Molecular sequelae of proteasome inhibition in human multiple myeloma cells. Proc. Natl. Acad. Sci. U. S. A. 99(22), 14374-14379.

118. Chauhan, D., Catley, L., Li, G., Podar, K., Hideshima, T., Velankar, M., Mitsiades, C., Mitsiades, N., Yasui, H., Letai, A., Ovaa, H., Berkers, C., Nicholson, B., Chao, T.H., Neuteboom, S.T., Richardson, P., Palladino, M.A., and Anderson, K.C. (2005) A novel orally active proteasome inhibitor induces apoptosis in multiple myeloma cells with mechanisms distinct from Bortezomib. Cancer Cell 8(5), 407-419.

119. Kawaguchi, Y., Kovacs, J.J., McLaurin, A., Vance, J.M., Ito, A., and Yao, T.P. (2003) The deacetylase HDAC6 regulates aggresome formation and cell viability in response to misfolded protein stress. Cell 115(6), 727-738.

120. Hideshima, T., Bradner, J.E., Wong, J., Chauhan, D., Richardson, P., Schreiber, S.L., and Anderson, K.C. (2005) Small-molecule inhibition of proteasome and aggresome function induces synergistic antitumor activity in multiple myeloma. Proc. Natl. Acad. Sci. U. S. A. 102(24), 8567-8572.

121. Mitsiades, C.S., Mitsiades, N.S., McMullan, C.J., Poulaki, V., Shringarpure, R., Hideshima, T., Akiyama, M., Chauhan, D., Munshi, N., Gu, X., Bailey, C., Joseph, M., Libermann, T.A., Richon, V.M., Marks, P.A., and Anderson, K.C. (2004) Transcriptional signature of histone deacetylase inhibition in multiple myeloma: biological and clinical implications. Proc. Natl. Acad. Sci. U. S. A. 101(2), 540-545.

122. Mitsiades, N., Mitsiades, C.S., Richardson, P.G., McMullan, C., Poulaki, V., Fanourakis, G., Schlossman, R., Chauhan, D., Munshi, N.C., Hideshima, T., Richon, V.M., Marks, P.A., and Anderson, K.C. (2003) Molecular sequelae of histone deacetylase inhibition in human malignant B cells. Blood 101(10), 4055-4062.

123. Whitesell, L. and Lindquist, S.L. (2005) HSP90 and the chaperoning of cancer. Nat. Rev. Cancer 5(10), 761-772.

124. Pratt, W.B. (1998) The hsp90-based chaperone system: involvement in signal transduction from a variety of hormone and growth factor receptors. Proc. Soc. Exp. Biol. Med. 217(4), 420-434.

125. Munster, P.N., Marchion, D.C., Basso, A.D., and Rosen, N. (2002) Degradation of HER2 by ansamycins induces growth arrest and apoptosis in cells with HER2 overexpression via a HER3, phosphatidylinositol 3'-kinase-AKTdependent pathway. Cancer Res. 62(11), 3132-3137.

126. Mimnaugh, E.G., Xu, W., Vos, M., Yuan, X., Isaacs, J.S., Bisht, K.S., Gius, D., and Neckers, L. (2004) Simultaneous inhibition of hsp 90 and the proteasome promotes protein ubiquitination, causes endoplasmic reticulum-derived cytosolic vacuolization, and enhances antitumor activity. Mol. Cancer Ther. 3(5), 551-566.

127. Rahmani, M., Yu, C., Dai, Y., Reese, E., Ahmed, W., Dent, P., and Grant, S. (2003) Coadministration of the heat shock protein 90 antagonist 17-allylamino- 17-demethoxygeldanamycin with suberoylanilide hydroxamic acid or sodium butyrate synergistically induces apoptosis in human leukemia cells. Cancer Res. 63(23), 8420-8427.

128. Mitsiades, C.S., Mitsiades, N., Rooney, M., Hideshima, T., Chauhan, D., Munshi, N.C., Johnson, R., Hannah, A., Richardson, P.G., and Anderson, K.C. (2004) Anti-Tumor Activity of KOS-953, a Cremophor-Based Formulation of the hsp90 Inhibitor 17-AAG. ASH Annual Meeting Abstracts. Blood 104(11), 2404.

129. Chanan-Khan, A.A., Richardson, P.G., Alsina, M., Carroll, M., Lonial, S., Krishnan, A., Albitar, M., Zhou, Y., Mitsiades, C., Cropp, G., Hannah, A.L., and Anderson, K.C. (2005) Phase 1 Clinical Trial of KOS-953 + Bortezomib (BZ) in Relapsed Refractory Multiple Myeloma (MM). ASH Annual Meeting Abstracts. Blood 106(11), 362.

130. Richardson, P.G., Chanan-Khan, A.A., Alsina, M., Doss, D., Landrigan, B., Kettner, D., Albitar, M., Mitsiades, C., Cropp, G.F., Johnson, R.G., Hannah, A.L., and Anderson, K.C. (2005) Safety and Activity of KOS-953 in Patients with Relapsed Refractory Multiple Myeloma (MM): Interim Results of a Phase 1 Trial. ASH Annual Meeting Abstracts. Blood 106(11), 361.

131. Jagannath, S., Siegel, D., Richardson, P., Mazumder, A., Sydor, J., Goddard, J., Walker, J., Patterson, J., Normant, E., Tong, J., Palombella, V., Anderson, K., Adams, J., and Grayzel, D. (2005) Phase I Clinical Trial of IPI-504, a Novel, Water-Soluble Hsp90 Inhibitor, in Patients with Relapsed/Refractory Multiple Myeloma (MM). ASH Annual Meeting Abstracts. Blood 106(11), 2560.

132. Palombella, V.J., Normant, E., Ali, J., Barrett, J., Foley, M., Gao, Y., Ge, J., Georges, A.T., Grayzel, D., Grenier, L., Hudak, J., Pak, R., Patterson, J., Pien, C., Pink, M., Porter, J., Sang, J., Spear, K., Sydor, J., Wright, J., Mitsiades, C.S., Anderson, K.C., Adams, J., and Tong, J. (2004) Anti-Tumor Activity of IPI-504, a Novel Hsp90 Inhibitor in Multiple Myeloma. ASH Annual Meeting Abstracts. Blood 104(11), 4922.

133. Mitsiades, C.S., Mitsiades, N., Rooney, M., Negri, J., Geer, C.C., Pink, M., Pien, C., Hideshima, T., Chauhan, D., Munshi, N.C., Richardson, P.G., Barrett, J., Tong, J.K., Grayzel, D., Palombella, V., Adams, J., and Anderson, K.C. (2004) IPI-504: A Novel hsp90 Inhibitor with In Vitro and In Vivo Anti-Tumor Activity. ASH Annual Meeting Abstracts. Blood 104(11), 2403.

134. Olovnikov, A.M. (1996) Telomeres, telomerase, and aging: origin of the theory. Exp. Gerontol. 31(4), $443-448$.

135. 
Munshi, N.C., and Anderson, K.C. (2003) Effects of oligonucleotide N3'-->P5' thio-phosphoramidate (GRN163) targeting telomerase RNA in human multiple myeloma cells. Cancer Res. 63(19), 6187-6194.

138. Shammas, M.A., Shmookler Reis, R.J., Li, C., Koley, H., Hurley, L.H., Anderson, K.C., and Munshi, N.C. (2004) Telomerase inhibition and cell growth arrest after telomestatin treatment in multiple myeloma. Clin. Cancer Res. 10(2), 770-776.

139. Chauhan, D., Uchiyama, H., Akbarali, Y., Urashima, M., Yamamoto, K., Libermann, T.A., and Anderson, K.C. (1996) Multiple myeloma cell adhesion-induced interleukin-6 expression in bone marrow stromal cells involves activation of NF-kappa B. Blood 87(3), 1104-1112.

140. Chauhan, D., Uchiyama, H., Urashima, M., Yamamoto, K., and Anderson, K.C. (1995) Regulation of interleukin 6 in multiple myeloma and bone marrow stromal cells. Stem Cells 13(Suppl 2), 35-39.

141. Frassanito, M.A., Cusmai, A., Iodice, G., and Dammacco, F. (2001) Autocrine interleukin-6 production and highly malignant multiple myeloma: relation with resistance to drug-induced apoptosis. Blood 97(2), 483-489.

142. Urashima, M., Ogata, A., Chauhan, D., Hatziyanni, M., Vidriales, M.B., Dedera, D.A., Schlossman, R.L., and Anderson, K.C. (1996) Transforming growth factor-beta1: differential effects on multiple myeloma versus normal B cells. Blood 87(5), 1928-1938.

143. Taga, T., Hibi, M., Hirata, Y., Yamasaki, K., Yasukawa, K., Matsuda, T., Hirano, T., and Kishimoto, T. (1989) Interleukin-6 triggers the association of its receptor with a possible signal transducer, gp130. Cell 58(3), 573-581.

144. Savino, R., Ciapponi, L., Lahm, A., Demartis, A., Cabibbo, A., Toniatti, C., Delmastro, P., Altamura, S., and Ciliberto, G. (1994) Rational design of a receptor super-antagonist of human interleukin-6. EMBO J. 13(24), 58635870 .

145. Savino, R., Lahm, A., Salvati, A.L., Ciapponi, L., Sporeno, E., Altamura, S., Paonessa, G., Toniatti, C., and Ciliberto, G. (1994) Generation of interleukin-6 receptor antagonists by molecular-modeling guided mutagenesis of residues important for gp130 activation. EMBO J. 13(6), 1357-1367.

146. Wendling, D., Racadot, E., and Wijdenes, J. (1993) Treatment of severe rheumatoid arthritis by anti-interleukin 6 monoclonal antibody. J. Rheumatol. 20(2), 259-262.

147. Kiberd, B.A. (1993) Interleukin-6 receptor blockage ameliorates murine lupus nephritis. J. Am. Soc. Nephrol. 4(1), $58-61$.

148. Vink, A., Coulie, P., Warnier, G., Renauld, J.C., Stevens, M., Donckers, D., and Van Snick, J. (1990) Mouse plasmacytoma growth in vivo: enhancement by interleukin 6 (IL-6) and inhibition by antibodies directed against IL-6 or its receptor. J. Exp. Med. 172(3), 997-1000.

149. Klein, B., Zhang, X.G., Lu, Z.Y., and Bataille, R. (1995) Interleukin-6 in human multiple myeloma. Blood 85(4), 863-872.

150. Trikha, M., Corringham, R., Klein, B., and Rossi, J.F. (2003) Targeted anti-interleukin-6 monoclonal antibody therapy for cancer: a review of the rationale and clinical evidence. Clin. Cancer Res. 9(13), 4653-4665.

151. Tassone, P., Neri, P., Burger, R., Savino, R., Shammas, M., Catley, L., Podar, K., Chauhan, D., Masciari, S., Gozzini, A., Tagliaferri, P., Venuta, S., Munshi, N.C., and Anderson, K.C. (2005) Combination therapy with interleukin-6 receptor superantagonist Sant7 and dexamethasone induces antitumor effects in a novel SCID-hu in vivo model of human multiple myeloma. Clin. Cancer Res. 11(11), 4251-4258.

152. Demartis, A., Bernassola, F., Savino, R., Melino, G., and Ciliberto, G. (1996) Interleukin 6 receptor superantagonists are potent inducers of human multiple myeloma cell death. Cancer Res. 56(18), 4213-4218.

153. Uchiyama, H., Barut, B.A., Mohrbacher, A.F., Chauhan, D., and Anderson, K.C. (1993) Adhesion of human myeloma-derived cell lines to bone marrow stromal cells stimulates interleukin-6 secretion. Blood 82(12), 37123720 .

154. Chauhan, D., Li, G., Hideshima, T., Podar, K., Mitsiades, C., Mitsiades, N., Catley, L., Tai, Y.T., Hayashi, T., Shringarpure, R., Burger, R., Munshi, N., Ohtake, Y., Saxena, S., and Anderson, K.C. (2003) Hsp27 inhibits release of mitochondrial protein Smac in multiple myeloma cells and confers dexamethasone resistance. Blood 102(9), 33793386.

155. Tassone, P., Forciniti, S., Galea, E., Savino, R., Turco, M.C., Iacopino, P., Tagliaferri, P., Morrone, G., Ciliberto, G., and Venuta, S. (2000) Synergistic induction of growth arrest and apoptosis of human myeloma cells by the IL-6 super-antagonist Sant7 and Dexamethasone. Cell Death Differ. 7(3), 327-328.

156. Tassone, P., Galea, E., Forciniti, S., Tagliaferri, P., and Venuta, S. (2002) The IL-6 receptor super-antagonist Sant7 enhances antiproliferative and apoptotic effects induced by dexamethasone and zoledronic acid on multiple myeloma cells. Int. J. Oncol. 21(4), 867-873.

157. Bisping, G., Leo, R., Wenning, D., Dankbar, B., Padro, T., Kropff, M., Scheffold, C., Kroger, M., Mesters, R.M., Berdel, W.E., and Kienast, J. (2003) Paracrine interactions of basic fibroblast growth factor and interleukin-6 in multiple myeloma. Blood 101(7), 2775-2783.

158. Sezer, O., Jakob, C., Eucker, J., Niemoller, K., Gatz, F., Wernecke, K., and Possinger, K. (2001) Serum levels of the angiogenic cytokines basic fibroblast growth factor (bFGF), vascular endothelial growth factor (VEGF) and hepatocyte growth factor (HGF) in multiple myeloma. Eur. J. Haematol. 66(2), 83-88.

159. Vacca, A., Ribatti, D., Presta, M., Minischetti, M., Iurlaro, M., Ria, R., Albini, A., Bussolino, F., and Dammacco, F. (1999) Bone marrow neovascularization, plasma cell angiogenic potential, and matrix metalloproteinase-2 secretion parallel progression of human multiple myeloma. Blood 93(9), 3064-3073. 
160. Raje, N., Kumar, S., Hideshima, T., Ishitsuka, K., Chauhan, D., Mitsiades, C., Podar, K., Le Gouill, S., Richardson, P., Munshi, N.C., Stirling, D.I., Antin, J.H., and Anderson, K.C. (2004) Combination of the mTOR inhibitor rapamycin and CC-5013 has synergistic activity in multiple myeloma. Blood 104(13), 4188-4193.

161. Chang, H., Stewart, A.K., Qi, X.Y., Li, Z.H., Yi, Q.L., and Trudel, S. (2005) Immunohistochemistry accurately predicts FGFR3 aberrant expression and $\mathrm{t}(4 ; 14)$ in multiple myeloma. Blood 106(1), 353-355.

162. Trudel, S., Ely, S., Farooqi, Y., Affer, M., Robbiani, D.F., Chesi, M., and Bergsagel, P.L. (2004) Inhibition of fibroblast growth factor receptor 3 induces differentiation and apoptosis in t(4;14) myeloma. Blood 103(9), 35213528.

163. Grand, E.K., Chase, A.J., Heath, C., Rahemtulla, A., and Cross, N.C. (2004) Targeting FGFR3 in multiple myeloma: inhibition of $\mathrm{t}(4 ; 14)$-positive cells by SU5402 and PD173074. Leukemia 18(5), 962-966.

164. Chen, J., Lee, B.H., Williams, I.R., Kutok, J.L., Mitsiades, C.S., Duclos, N., Cohen, S., Adelsperger, J., Okabe, R., Coburn, A., Moore, S., Huntly, B.J., Fabbro, D., Anderson, K.C., Griffin, J.D., and Gilliland, D.G. (2005) FGFR3 as a therapeutic target of the small molecule inhibitor PKC412 in hematopoietic malignancies. Oncogene 24(56), 82598267.

165. Trudel, S., Stewart, A.K., Rom, E., Wei, E., Li, Z.H., Kotzer, S., Chumakov, I., Singer, Y., Chang, H., Liang, S.B., and Yayon, A. (2006) The inhibitory anti-FGFR3 antibody, PRO-001 is cytotoxic to t(4;14) multiple myeloma cells. Blood 107(10), 4039-4046

166. Qiang, Y.W., Kopantzev, E., and Rudikoff, S. (2002) Insulinlike growth factor-I signaling in multiple myeloma: downstream elements, functional correlates, and pathway cross-talk. Blood 99(11), 4138-4146.

167. Pollak, M.N., Schernhammer, E.S., and Hankinson, S.E. (2004) Insulin-like growth factors and neoplasia. Nat. Rev. Cancer 4(7), 505-518.

168. Jelinek, D.F., Witzig, T.E., and Arendt, B.K. (1997) A role for insulin-like growth factor in the regulation of IL-6responsive human myeloma cell line growth. J. Immunol. 159(1), 487-496.

169. Mitsiades, C.S., Mitsiades, N., Poulaki, V., Schlossman, R., Akiyama, M., Chauhan, D., Hideshima, T., Treon, S.P., Munshi, N.C., Richardson, P.G., and Anderson, K.C. (2002) Activation of NF-kappaB and upregulation of intracellular anti-apoptotic proteins via the IGF-1/Akt signaling in human multiple myeloma cells: therapeutic implications. Oncogene 21(37), 5673-5683.

170. Mitsiades, C.S., Mitsiades, N.S., McMullan, C.J., Poulaki, V., Shringarpure, R., Akiyama, M., Hideshima, T., Chauhan, D., Joseph, M., Libermann, T.A., Garcia-Echeverria, C., Pearson, M.A., Hofmann, F., Anderson, K.C., and Kung, A.L. (2004) Inhibition of the insulin-like growth factor receptor-1 tyrosine kinase activity as a therapeutic strategy for multiple myeloma, other hematologic malignancies, and solid tumors. Cancer Cell 5(3), 221-230.

171. Podar, K., Tai, Y.T., Davies, F.E., Lentzsch, S., Sattler, M., Hideshima, T., Lin, B.K., Gupta, D., Shima, Y., Chauhan, D., Mitsiades, C., Raje, N., Richardson, P., and Anderson, K.C. (2001) Vascular endothelial growth factor triggers signaling cascades mediating multiple myeloma cell growth and migration. Blood 98(2), 428-435.

172. Podar, K., Tai, Y.T., Lin, B.K., Narsimhan, R.P., Sattler, M., Kijima, T., Salgia, R., Gupta, D., Chauhan, D., and Anderson, K.C. (2002) Vascular endothelial growth factor-induced migration of multiple myeloma cells is associated with beta 1 integrin- and phosphatidylinositol 3-kinase-dependent PKC alpha activation. J. Biol. Chem. 277(10), 7875-7881.

173. Dankbar, B., Padro, T., Leo, R., Feldmann, B., Kropff, M., Mesters, R.M., Serve, H., Berdel, W.E., and Kienast, J. (2000) Vascular endothelial growth factor and interleukin-6 in paracrine tumor-stromal cell interactions in multiple myeloma. Blood 95(8), 2630-2636.

174. Gupta, D., Treon, S.P., Shima, Y., Hideshima, T., Podar, K., Tai, Y.T., Lin, B., Lentzsch, S., Davies, F.E., Chauhan, D., Schlossman, R.L., Richardson, P., Ralph, P., Wu, L., Payvandi, F., Muller, G., Stirling, D.I., and Anderson, K.C. (2001) Adherence of multiple myeloma cells to bone marrow stromal cells upregulates vascular endothelial growth factor secretion: therapeutic applications. Leukemia 15(12), 1950-1961.

175. Le Gouill, S., Podar, K., Amiot, M., Hideshima, T., Chauhan, D., Ishitsuka, K., Kumar, S., Raje, N., Richardson, P.G., Harousseau, J.L., and Anderson, K.C. (2004) VEGF induces Mcl-1 up-regulation and protects multiple myeloma cells against apoptosis. Blood 104(9), 2886-2892.

176. Hurwitz, H., Fehrenbacher, L., Novotny, W., Cartwright, T., Hainsworth, J., Heim, W., Berlin, J., Baron, A., Griffing, S., Holmgren, E., Ferrara, N., Fyfe, G., Rogers, B., Ross, R., and Kabbinavar, F. (2004) Bevacizumab plus irinotecan, fluorouracil, and leucovorin for metastatic colorectal cancer. N. Engl. J. Med. 350(23), 2335-2342.

177. Lin, B., Podar, K., Gupta, D., Tai, Y.T., Li, S., Weller, E., Hideshima, T., Lentzsch, S., Davies, F., Li, C., Weisberg, E., Schlossman, R.L., Richardson, P.G., Griffin, J.D., Wood, J., Munshi, N.C., and Anderson, K.C. (2002) The vascular endothelial growth factor receptor tyrosine kinase inhibitor PTK787/ZK222584 inhibits growth and migration of multiple myeloma cells in the bone marrow microenvironment. Cancer Res. 62(17), 5019-5026.

178. Mendel, D.B., Laird, A.D., Smolich, B.D., Blake, R.A., Liang, C., Hannah, A.L., Shaheen, R.M., Ellis, L.M., Weitman, S., Shawver, L.K., and Cherrington, J.M. (2000) Development of SU5416, a selective small molecule inhibitor of VEGF receptor tyrosine kinase activity, as an anti-angiogenesis agent. Anticancer Drug Des. 15(1), 2941.

179. Mendel, D.B., Schreck, R.E., West, D.C., Li, G., Strawn, L.M., Tanciongco, S.S., Vasile, S., Shawver, L.K., and Cherrington, J.M. (2000) The angiogenesis inhibitor SU5416 has long-lasting effects on vascular endothelial growth factor receptor phosphorylation and function. Clin. Cancer Res. 6(12), 4848-4858. 
180. Podar, K., Catley, L.P., Tai, Y.T., Shringarpure, R., Carvalho, P., Hayashi, T., Burger, R., Schlossman, R.L., Richardson, P.G., Pandite, L.N., Kumar, R., Hideshima, T., Chauhan, D., and Anderson, K.C. (2004) GW654652, the pan-inhibitor of VEGF receptors, blocks the growth and migration of multiple myeloma cells in the bone marrow microenvironment. Blood 103(9), 3474-3479.

181. Zangari, M., Anaissie, E., Stopeck, A., Morimoto, A., Tan, N., Lancet, J., Cooper, M., Hannah, A., Garcia-Manero, G., Faderl, S., Kantarjian, H., Cherrington, J., Albitar, M., and Giles, F.J. (2004) Phase II study of SU5416, a small molecule vascular endothelial growth factor tyrosine kinase receptor inhibitor, in patients with refractory multiple myeloma. Clin. Cancer Res. 10(1 Pt 1), 88-95.

182. Mitsiades, C.S., Treon, S.P., Mitsiades, N., Shima, Y., Richardson, P., Schlossman, R., Hideshima, T., and Anderson, K.C. (2001) TRAIL/Apo2L ligand selectively induces apoptosis and overcomes drug resistance in multiple myeloma: therapeutic applications. Blood 98(3), 795-804.

183. Mitsiades, N., Mitsiades, C.S., Poulaki, V., Anderson, K.C., and Treon, S.P. (2001) Concepts in the use of TRAIL/Apo2L: an emerging biotherapy for myeloma and other neoplasias. Expert Opin. Investig. Drugs 10(8), 15211530.

184. Tai, Y.T., Podar, K., Mitsiades, N., Lin, B., Mitsiades, C., Gupta, D., Akiyama, M., Catley, L., Hideshima, T., Munshi, N.C., Treon, S.P., and Anderson, K.C. (2003) CD40 induces human multiple myeloma cell migration via phosphatidylinositol 3-kinase/AKT/NF-kappa B signaling. Blood 101(7), 2762-2769.

185. Tai, Y.T., Li, X., Tong, X., Santos, D., Otsuki, T., Catley, L., Tournilhac, O., Podar, K., Hideshima, T., Schlossman, R., Richardson, P., Munshi, N.C., Luqman, M., and Anderson, K.C. (2005) Human anti-CD40 antagonist antibody triggers significant antitumor activity against human multiple myeloma. Cancer Res. 65(13), 5898-5906.

186. Hayashi, T., Hideshima, T., Nguyen, A.N., Munoz, O., Podar, K., Hamasaki, M., Ishitsuka, K., Yasui, H., Richardson, P., Chakravarty, S., Murphy, A., Chauhan, D., Higgins, L.S., and Anderson, K.C. (2004) Transforming growth factor beta receptor I kinase inhibitor down-regulates cytokine secretion and multiple myeloma cell growth in the bone marrow microenvironment. Clin. Cancer Res. 10(22), 7540-7546.

187. San Miguel, J.F., Gonzalez, M., Gascon, A., Moro, M.J., Hernandez, J.M., Ortega, F., Jimenez, R., Guerras, L., Romero, M., Casanova, F., et al. (1991) Immunophenotypic heterogeneity of multiple myeloma: influence on the biology and clinical course of the disease. Castellano-Leones (Spain) Cooperative Group for the Study of Monoclonal Gammopathies. Br. J. Haematol. 77(2), 185-190.

188. Treon, S.P. and Anderson, K.C. (2000) The use of rituximab in the treatment of malignant and nonmalignant plasma cell disorders. Semin. Oncol. 27(6 Suppl 12), 79-85.

189. Treon, S.P., Pilarski, L.M., Belch, A.R., Kelliher, A., Preffer, F.I., Shima, Y., Mitsiades, C.S., Mitsiades, N.S., Szczepek, A.J., Ellman, L., Harmon, D., Grossbard, M.L., and Anderson, K.C. (2002) CD20-directed serotherapy in patients with multiple myeloma: biologic considerations and therapeutic applications. J. Immunother. 25(1), $72-81$.

190. Boye, J., Elter, T., and Engert, A. (2003) An overview of the current clinical use of the anti-CD20 monoclonal antibody rituximab. Ann. Oncol. 14(4), 520-535.

191. Hussein, M.A., Saleh, M., Ravandi, F., Mason, J., Rifkin, R.M., and Ellison, R. (2004) Phase 2 study of arsenic trioxide in patients with relapsed or refractory multiple myeloma. Br. J. Haematol. 125(4), 470-476.

192. Borad, M.J., Swift, R., and Berenson, J.R. (2005) Efficacy of melphalan, arsenic trioxide, and ascorbic acid combination therapy (MAC) in relapsed and refractory multiple myeloma. Leukemia 19(1), 154-156.

193. Grad, J.M., Bahlis, N.J., Reis, I., Oshiro, M.M., Dalton, W.S., and Boise, L.H. (2001) Ascorbic acid enhances arsenic trioxide-induced cytotoxicity in multiple myeloma cells. Blood 98(3), 805-813.

194. Richardson, P., Schlossman, R., Jagannath, S., Alsina, M., Desikan, R., Blood, E., Weller, E., Mitsiades, C., Hideshima, T., Davies, F., Doss, D., Freeman, A., Bosch, J., Patin, J., Knight, R., Zeldis, J., Dalton, W., and Anderson, K. (2004) Thalidomide for patients with relapsed multiple myeloma after high-dose chemotherapy and stem cell transplantation: results of an open-label multicenter phase 2 study of efficacy, toxicity, and biological activity. Mayo Clin. Proc. 79(7), 875-882.

195. Strasser, K. and Ludwig, H. (2002) Thalidomide treatment in multiple myeloma. Blood Rev. 16(4), $207-215$.

196. Tosi, P., Zamagni, E., Cellini, C., Ronconi, S., Patriarca, F., Ballerini, F., Musto, P., Di Raimondo, F., Ledda, A., Lauria, F., Masini, L., Gobbi, M., Vacca, A., Ria, R., Cangini, D., Tura, S., Baccarani, M., and Cavo, M. (2002) Salvage therapy with thalidomide in patients with advanced relapsed/refractory multiple myeloma. Haematologica 87(4), 408-414.

197. Rajkumar, S.V., Dispenzieri, A., Fonseca, R., Lacy, M.Q., Geyer, S., Lust, J.A., Kyle, R.A., Greipp, P.R., Gertz, M.A., and Witzig, T.E. (2001) Thalidomide for previously untreated indolent or smoldering multiple myeloma. Leukemia 15(8), 1274-1276.

198. Rajkumar, S.V., Gertz, M.A., Lacy, M.Q., Dispenzieri, A., Fonseca, R., Geyer, S.M., Iturria, N., Kumar, S., Lust, J.A., Kyle, R.A., Greipp, P.R., and Witzig, T.E. (2003) Thalidomide as initial therapy for early-stage myeloma. Leukemia 17(4), 775-779.

199. Rajkumar, S.V., Hayman, S., Gertz, M.A., Dispenzieri, A., Lacy, M.Q., Greipp, P.R., Geyer, S., Iturria, N., Fonseca, R., Lust, J.A., Kyle, R.A., and Witzig, T.E. (2002) Combination therapy with thalidomide plus dexamethasone for newly diagnosed myeloma. J. Clin. Oncol. 20(21), 4319-4323.

200. Dingli, D., Rajkumar, S.V., Nowakowski, G.S., Gertz, M.A., Dispenzieri, A., Lacy, M.Q., Hayman, S., Fonseca, R., Lust, J.A., Kyle, R.A., Greipp, P.R., and Witzig, T.E. (2005) Combination therapy with thalidomide and 
dexamethasone in patients with newly diagnosed multiple myeloma not undergoing upfront autologous stem cell transplantation: a phase II trial. Haematologica 90(12), 1650-1654.

201. Ochiai, N., Yamada, N., Uchida, R., Fuchida, S., Okano, A., Hatsuse, M., Okamoto, M., Ashihara, E., and Shimazaki, C. (2005) Combination therapy with thalidomide, incadronate, and dexamethasone for relapsed or refractory multiple myeloma. Int. J. Hematol. 82(3), 243-247.

202. Palladini, G., Perfetti, V., Perlini, S., Obici, L., Lavatelli, F., Caccialanza, R., Invernizzi, R., Comotti, B., and Merlini, G. (2005) The combination of thalidomide and intermediate-dose dexamethasone is an effective but toxic treatment for patients with primary amyloidosis (AL). Blood 105(7), 2949-2951.

203. Palumbo, A., Bertola, A., Falco, P., Rosato, R., Cavallo, F., Giaccone, L., Bringhen, S., Musto, P., Pregno, P., Caravita, T., Ciccone, G., and Boccadoro, M. (2004) Efficacy of low-dose thalidomide and dexamethasone as first salvage regimen in multiple myeloma. Hematol. J. 5(4), 318-324.

204. Palumbo, A., Giaccone, L., Bertola, A., Pregno, P., Bringhen, S., Rus, C., Triolo, S., Gallo, E., Pileri, A., and Boccadoro, M. (2001) Low-dose thalidomide plus dexamethasone is an effective salvage therapy for advanced myeloma. Haematologica 86(4), 399-403.

205. Rajkumar, S.V., Blood, E., Vesole, D., Fonseca, R., and Greipp, P.R. (2006) Phase III clinical trial of thalidomide plus dexamethasone compared with dexamethasone alone in newly diagnosed multiple myeloma: a clinical trial coordinated by the Eastern Cooperative Oncology Group. J. Clin. Oncol. 24(3), 431-436.

206. Schutt, P., Ebeling, P., Buttkereit, U., Brandhorst, D., Opalka, B., Poser, M., Muller, S., Flasshove, M., Moritz, T., Seeber, S., and Nowrousian, M.R. (2005) Thalidomide in combination with dexamethasone for pretreated patients with multiple myeloma: serum level of soluble interleukin-2 receptor as a predictive factor for response rate and for survival. Ann. Hematol. 84(9), 594-600.

207. Dimopoulos, M.A., Hamilos, G., Zomas, A., Gika, D., Efstathiou, E., Grigoraki, V., Poziopoulos, C., Xilouri, I., Zorzou, M.P., Anagnostopoulos, N., and Anagnostopoulos, A. (2004) Pulsed cyclophosphamide, thalidomide and dexamethasone: an oral regimen for previously treated patients with multiple myeloma. Hematol. J. 5(2), 112-117.

208. Garcia-Sanz, R., Gonzalez-Porras, J.R., Hernandez, J.M., Polo-Zarzuela, M., Sureda, A., Barrenetxea, C., Palomera, L., Lopez, R., Grande-Garcia, C., Alegre, A., Vargas-Pabon, M., Gutierrez, O.N., Rodriguez, J.A., and San Miguel, J.F. (2004) The oral combination of thalidomide, cyclophosphamide and dexamethasone (ThaCyDex) is effective in relapsed/refractory multiple myeloma. Leukemia 18(4), 856-863.

209. Kropff, M.H., Lang, N., Bisping, G., Domine, N., Innig, G., Hentrich, M., Mitterer, M., Sudhoff, T., Fenk, R., Straka, C., Heinecke, A., Koch, O.M., Ostermann, H., Berdel, W.E., and Kienast, J. (2003) Hyperfractionated cyclophosphamide in combination with pulsed dexamethasone and thalidomide (HyperCDT) in primary refractory or relapsed multiple myeloma. Br. J. Haematol. 122(4), 607-616.

210. Kyriakou, C., Thomson, K., D'Sa, S., Flory, A., Hanslip, J., Goldstone, A.H., and Yong, K.L. (2005) Low-dose thalidomide in combination with oral weekly cyclophosphamide and pulsed dexamethasone is a well tolerated and effective regimen in patients with relapsed and refractory multiple myeloma. Br. J. Haematol. 129(6), 763-770.

211. Palumbo, A., Bringhen, S., Musto, P., Caravita, T., Capozzi, R., Callea, V., Cangialosi, C., Montanaro, M., Catalano, L., Grasso, M., Petti, M.C., Merla, M., Falchi, L., Omede, P., Ceccarelli, M., Ambrosini, M.T., Avonto, I., Gay, F., Falco, P., and Boccadoro, M. (2005) Oral Melphalan, Prednisone and Thalidomide for Multiple Myeloma. ASH Annual Meeting Abstracts. Blood 106(11), 779.

212. Attal, M., Harousseau, J.-L., Leyvraz, S., Doyen, C., Hulin, C., Benboubker, L., Facon, T., Bourhis, J.-H., Garderet, L., Sotto, J.-J., Michallet, M., Renaud, M., Voillat, L., Berthou, C., Marrit, G., Monconduit, M., Coiffier, B., and Caillot, D. (2004) Maintenance Treatment with Thalidomide after Autologous Transplantation for Myeloma: First Analysis of a Prospective Randomized Study of the Intergroupe Francophone du Myelome (IFM 99 02). ASH Annual Meeting Abstracts. Blood 104(11), 535.

213. Attal, M., Harousseau, J.-L., Leyvraz, S., Doyen, C., Hulin, C., Benboubker, L., Agha, I.Y., Bourhis, J.-H., Garderet, L., Sotto, J.-J., Michallet, M., Renaud, M., Voillat, L., Berthou, C., Marit, G., Monconduit, M., Dumonte, C., Caillot, D., Mathiot, C., Avet-Loiseau, H., and for the, I.F.M. (2005) Maintenance Treatment with Thalidomide after Autologous Transplantation for Myeloma: Final Analysis of a Prospective Randomized Study of the "Intergroupe Francophone du Myelome". ASH Annual Meeting Abstracts. Blood 106(11), 1148.

214. Facon, T., Mary, J.Y., Hulin, C., Benboubker, L., Attal, M., Renaud, M., Harousseau, J.L., Pegourie, B., Guillerm, G., Chaleteix, C., Dib, M., Voillat, L., Maisonneuve, H., Troncy, J., Dorvaux, V., Monconduit, M., Martin, C., Casassus, P., Jaubert, J., Jardel, H., Kolb, B., and Bauters, F. (2005) Major Superiority of Melphalan - Prednisone (MP) + Thalidomide (THAL) over MP and Autologous Stem Cell Transplantation in the Treatment of Newly Diagnosed Elderly Patients with Multiple Myeloma. ASH Annual Meeting Abstracts. Blood 106(11), 780.

215. (2003) CC-5013 MM 0017: a multicenter, randomized, parallel-group, double-blind, placebo-controlled study of CC5013 plus dexamethasone versus dexamethasone alone in previously treated subjects with multiple myeloma. Clin. Adv. Hematol. Oncol. 1(3), 189-190.

216. Richardson, P.G., Schlossman, R.L., Weller, E., Hideshima, T., Mitsiades, C., Davies, F., LeBlanc, R., Catley, L.P., Doss, D., Kelly, K., McKenney, M., Mechlowicz, J., Freeman, A., Deocampo, R., Rich, R., Ryoo, J.J., Chauhan, D., Balinski, K., Zeldis, J., and Anderson, K.C. (2002) Immunomodulatory drug CC-5013 overcomes drug resistance and is well tolerated in patients with relapsed multiple myeloma. Blood 100(9), 3063-3067.

217. Rajkumar, S.V., Hayman, S.R., Lacy, M.Q., Dispenzieri, A., Geyer, S.M., Kabat, B., Zeldenrust, S.R., Kumar, S., 
Greipp, P.R., Fonseca, R., Lust, J.A., Russell, S.J., Kyle, R.A., Witzig, T.E., and Gertz, M.A. (2005) Combination therapy with lenalidomide plus dexamethasone (Rev/Dex) for newly diagnosed myeloma. Blood 106(13), 4050-4053.

218. Dimopoulos, M.A., Spencer, A., Attal, M., Prince, M., Harousseau, J.-L., Dmoszynska, A., Yu, Z., Olesnyckyj, M., Zeldis, J., and Knight, R. (2005) Study of Lenalidomide Plus Dexamethasone Versus Dexamethasone Alone in Relapsed or Refractory Multiple Myeloma (MM): Results of a Phase 3 Study (MM-010). ASH Annual Meeting Abstracts. Blood 106(11), 6.

219. NCT00098475, C.t., A Randomized Phase III Study of CC-5013 plus Dexamethasone versus CC-5013 plus Low Dose Dexamethasone in Multiple Myeloma With Thalidomide plus Dexamethasone Salvage Therapy for NonResponders. 2006.

220. Richardson, P.G., Barlogie, B., Berenson, J., Singhal, S., Jagannath, S., Irwin, D., Rajkumar, S.V., Srkalovic, G., Alsina, M., Alexanian, R., Siegel, D., Orlowski, R.Z., Kuter, D., Limentani, S.A., Lee, S., Hideshima, T., Esseltine, D.-L., Kauffman, M., Adams, J., Schenkein, D.P., and Anderson, K.C. (2003) A phase 2 study of bortezomib in relapsed, refractory myeloma. N. Engl. J. Med. 348, 2609-2617.

221. Jagannath, S., Barlogie, B., Berenson, J., Siegel, D., Irwin, D., Richardson, P.G., Niesvizky, R., Alexanian, R., Limentani, S.A., Alsina, M., Adams, J., Kauffman, M., Esseltine, D.L., Schenkein, D.P., and Anderson, K.C. (2004) A phase 2 study of two doses of bortezomib in relapsed or refractory myeloma. Br. J. Haematol. 127(2), 165-172.

222. Richardson, P.G., Sonneveld, P., Schuster, M.W., Irwin, D., Stadtmauer, E.A., Facon, T., Harousseau, J.L., BenYehuda, D., Lonial, S., Goldschmidt, H., Reece, D., San-Miguel, J.F., Blade, J., Boccadoro, M., Cavenagh, J., Dalton, W.S., Boral, A.L., Esseltine, D.L., Porter, J.B., Schenkein, D., and Anderson, K.C. (2005) Bortezomib or high-dose dexamethasone for relapsed multiple myeloma. N. Engl. J. Med. 352(24), 2487-2498.

223. Orlowski, R.Z., Voorhees, P.M., Garcia, R.A., Hall, M.D., Kudrik, F.J., Allred, T., Johri, A.R., Jones, P.E., Ivanova, A., Van Deventer, H.W., Gabriel, D.A., Shea, T.C., Mitchell, B.S., Adams, J., Esseltine, D.L., Trehu, E.G., Green, M., Lehman, M.J., Natoli, S., Collins, J.M., Lindley, C.M., and Dees, E.C. (2005) Phase 1 trial of the proteasome inhibitor bortezomib and pegylated liposomal doxorubicin in patients with advanced hematologic malignancies. Blood 105(8), 3058-3065.

224. Berenson, J., Yang, H., Swift, R., Sadler, K., Vescio, R., Adams, J., and Schenkein, D. (2004) Bortezomib in Combination with Melphalan in the Treatment of Relapsed or Refractory Multiple Myeloma: A Phase I/II Study. ASH Annual Meeting Abstracts. Blood 104(11), 209.

225. Hollmig, K., Stover, J., Talamo, G., Fassas, A., Lee, C.-K., Anaissie, E., Tricot, G., and Barlogie, B. (2004) Bortezomib (VelcadeTM) + AdriamycinTM + Thalidomide + Dexamethasone (VATD) as an Effective Regimen in Patients with Refractory or Relapsed Multiple Myeloma (MM). ASH Annual Meeting Abstracts. Blood 104(11), 2399.

226. Chanan-Khan, A.A., Miller, K.C., McCarthy, P., DiMiceli, L.A., Yu, J., Bernstein, Z.P., and Czuczman, M.S. (2004) A Phase II Study of Velcade (V), Doxil (D) in Combination with Low-Dose Thalidomide (T) as Salvage Therapy for Patients (pts) with Relapsed (rel) or Refractory (ref) Multiple Myeloma (MM) and Waldenstorm Macroglobulinemia (WM): Encouraging Preliminary Results. ASH Annual Meeting Abstracts. Blood 104(11), 2421.

227. Zangari, M., Barlogie, B., Burns, M.J., Bolejack, V., Hollmig, K.A., van Rhee, F., Pineda-Roman, M., Elice, F., and Tricot, G.J. (2005) Velcade (V)-Thalidomide (T)-Dexamethasone (D) for Advanced and Refractory Multiple Myeloma (MM): Long-Term Follow-Up of Phase I-II Trial UARK 2001-37: Superior Outcome in Patients with Normal Cytogenetics and No Prior T. ASH Annual Meeting Abstracts. Blood 106(11), 2552.

228. Zangari, M., Barlogie, B., Hollmig, K., Fassas, A., Rasmussen, E., Thertulien, R., Talamo, G., Lee, C.-K., and Tricot, G. (2004) Marked Activity of Velcade Plus Thalidomide (V+T) in Advanced and Refractory Multiple Myeloma (MM). ASH Annual Meeting Abstracts. Blood 104(11), 1480.

229. Jagannath, S., Durie, B.G., Wolf, J., Camacho, E., Irwin, D., Lutzky, J., McKinley, M., Gabayan, E., Mazumder, A., Schenkein, D., and Crowley, J. (2005) Bortezomib therapy alone and in combination with dexamethasone for previously untreated symptomatic multiple myeloma. Br. J. Haematol. 129(6), 776-783.

230. Oakervee, H.E., Popat, R., Curry, N., Smith, P., Morris, C., Drake, M., Agrawal, S., Stec, J., Schenkein, D., Esseltine, D.L., and Cavenagh, J.D. (2005) PAD combination therapy (PS-341/bortezomib, doxorubicin and dexamethasone) for previously untreated patients with multiple myeloma. Br. J. Haematol. 129(6), 755-762.

231. Wang, L.M., Weber, D.M., Delasalle, K.B., and Alexanian, R. (2004) VTD (Velcade, Thalidomide, Dexamethasone) as Primary Therapy for Newly-Diagnosed Multiple Myeloma. ASH Annual Meeting Abstracts. Blood 104(11), 210.

\section{This article should be cited as follows:}

Hwang, J.J., Ghobrial, I.M., and Anderson, K.C. (2006) New frontiers in the treatment of multiple myeloma. TheScientificWorldJOURNAL 6, 1475-1503. DOI 10.1100/tsw.2006.236. 


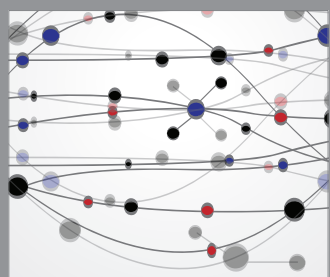

The Scientific World Journal
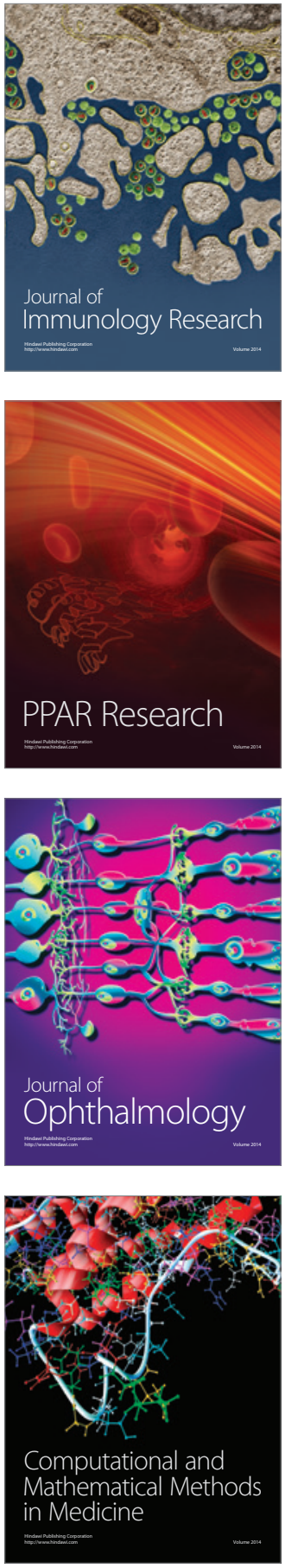

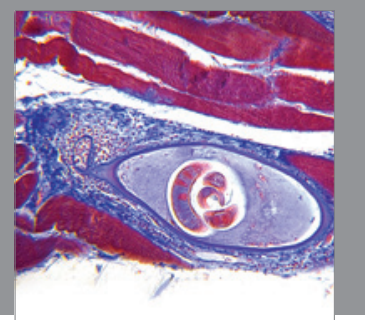

Gastroenterology

Research and Practice
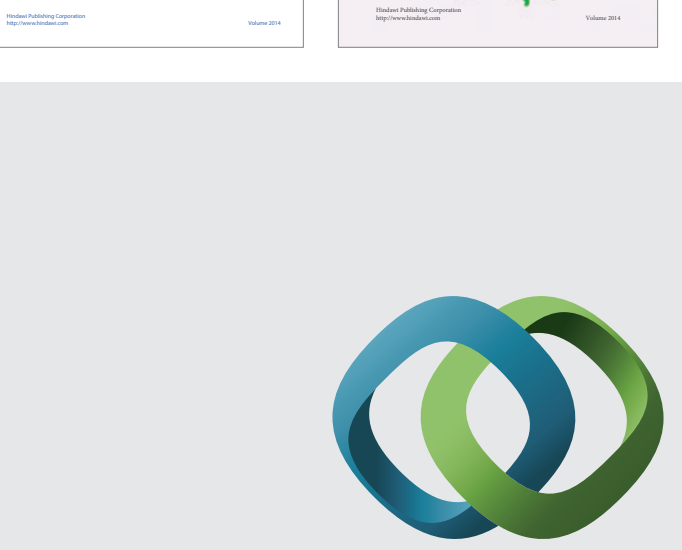

\section{Hindawi}

Submit your manuscripts at

http://www.hindawi.com
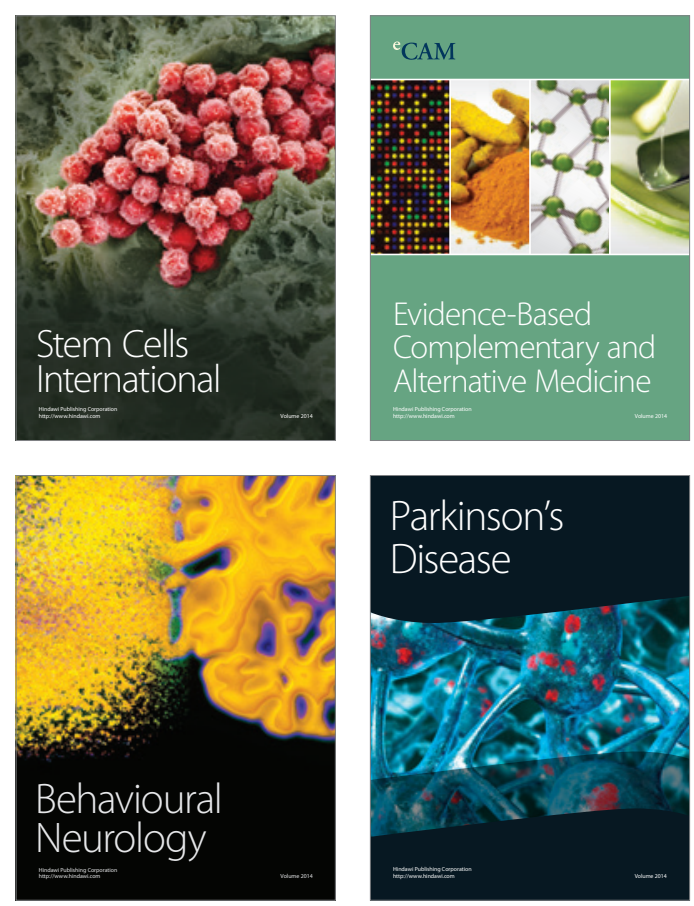

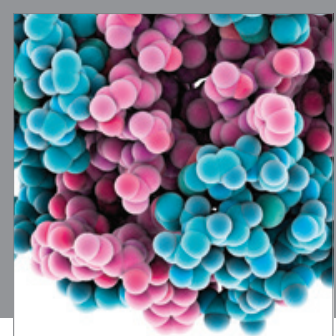

Journal of
Diabetes Research

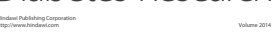

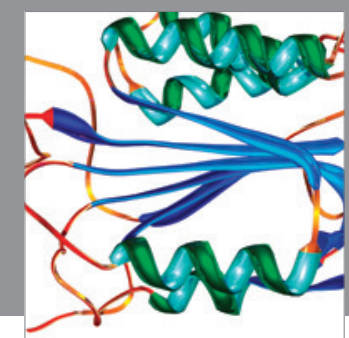

Disease Markers
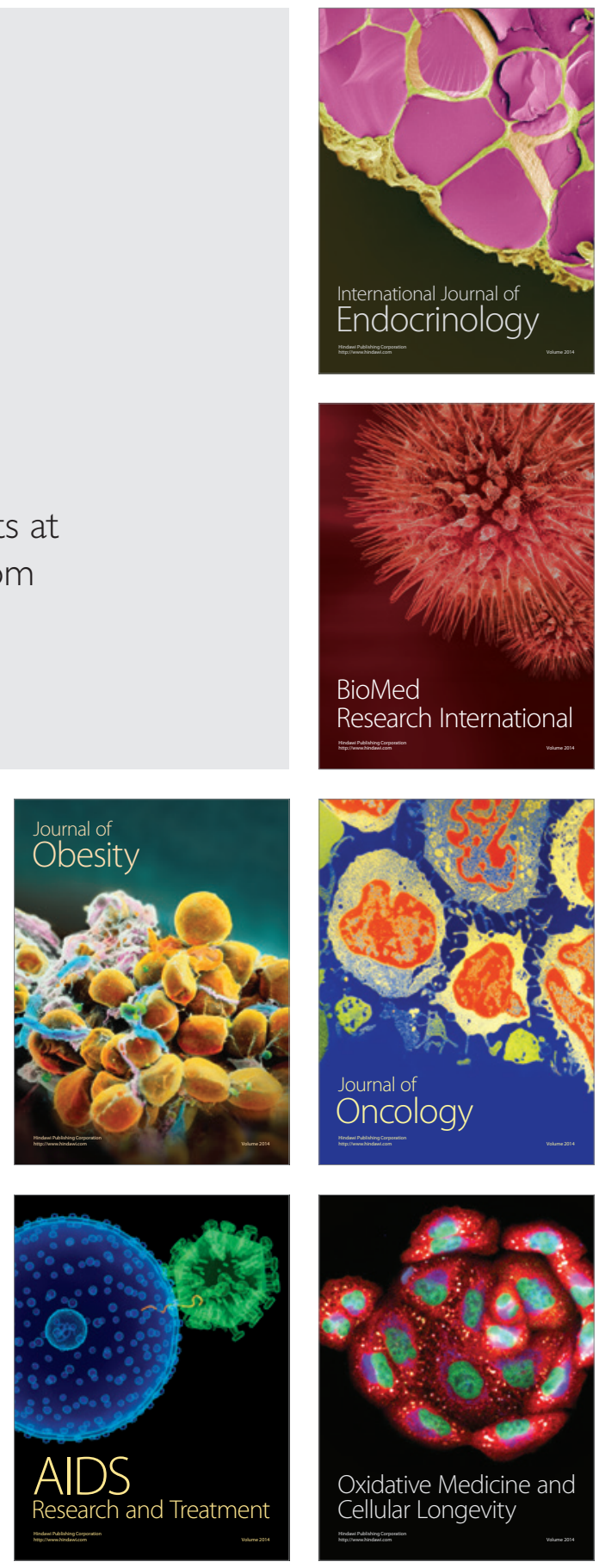